\title{
Sustainability of sugarcane production in Brazil. A review
}

\author{
Ricardo de Oliveira Bordonal ${ }^{1}$. João Luís Nunes Carvalho ${ }^{1} \cdot$ Rattan Lal $^{2} \cdot$ Eduardo Barretto de Figueiredo $^{3}$. \\ Bruna Gonçalves de Oliveira ${ }^{4}$ Newton La Scala $\mathrm{Jr}^{5}$
}

Accepted: 7 February 2018 / Published online: 27 February 2018

(C) INRA and Springer-Verlag France SAS, part of Springer Nature 2018

\begin{abstract}
Brazil is a major sugarcane producer and its production more than doubled over the last decades to meet global bioenergy demands for reducing crude oil dependency and mitigating climate change. Nevertheless, the adverse effects of this growth on jeopardizing the sustainability of sugarcane production are not known, especially when environmental impacts of agricultural inputs and production processes are not judiciously managed. This article is a comprehensive review of the state-of-the-knowledge and the main advances made thus far in the sugarcane sector. Here, we review the major environmental impacts of rapidly expanding sugarcane plantation on the land use change and its competition with food production, as well as those associated with sugarcane cultivation in Brazil. Our main finding are that sugarcane plantation did not contribute to direct deforestation, and its expansion on degraded pastures with the attendant increased yields of food crops and livestock intensification decreased land competition between food and sugarcane. Non-burning sugarcane harvesting is a win-win strategy because of its benefits involving agronomic and environmental aspects, but soil compaction is among the main issues in sugarcane cropping systems. Sugarcane is highly efficient in terms of nitrogen use efficiency, which is an important factor for its high energy balance. But, special attention should be given regarding emissions of nitrous oxide when straw mulching is combined with application of nitrogen fertilizer and vinasse. Recent advances in the sugarcane sector also show significant reductions in water consumption, making sugarcane ethanol one of the most favorable options in terms of water footprint. Growing realization of a vast potential indicates the need to further enhance the environmental benefits of sugarcane ethanol by optimizing the agricultural production chain. Based on this improved knowledge, the adoption of best management practices is among researchable priorities that can be developed to consolidate the large potential of sugarcane production towards greater sustainability.
\end{abstract}

Keywords Ethanol production · Food security · Water resources · Sugarcane harvest · Land use change · Greenhouse gas mitigation

Ricardo de Oliveira Bordonal

rbordonal@yahoo.com.br

1 CTBE/CNPEM - Brazilian Bioethanol Science and Technology Laboratory/Brazilian Center for Research in Energy and Materials, Rua Giuseppe Máximo Scolfaro 10000, Polo II de Alta Tecnologia, Campinas, SP 13083-100, Brazil

2 Carbon Management \& Sequestration Center, The Ohio State University, 210 Kottman Hall, 2021 Coffey Rd, Columbus, OH 43210, USA

3 Department of Rural Development, UFSCAR - Federal University of São Carlos, Rodovia Anhanguera Km 174, Araras, SP, Brazil

4 Soils and Environmental Resources Center, IAC - Agronomic Institute of Campinas, Barão de Itapura 1481,

Campinas, SP 13001-970, Brazil

5 FCAV/UNESP - Department of Exact Sciences, College of Agricultural and Veterinarian Sciences/São Paulo State University, Via de Acesso Prof. Paulo Donato Castellane s/n, Jaboticabal, SP 14884-900, Brazil

\section{Contents}

1. Introduction

2. Impact of sugarcane expansion on land use change

3. Land competition versus food production

3.1. Opportunities for agricultural intensification

4. Sugarcane production-related impacts

4.1. Green mechanized harvesting and tillage practices

4.2. Inorganic synthetic $\mathrm{N}$ fertilizer

4.3. Vinasse fertirrigation

4.4. Water use and quality

5. Conclusions

Acknowledgements

References 


\section{Introduction}

The ever increasing concentration of anthropogenic greenhouse gases (GHGs) has a causal link with some external drivers of climate change and with the observed changes in climatic impacts (e.g., precipitation intensity, cyclones, floods, and droughts; IPCC 2013). The observed increase in global temperature is largely driven by the burning of fossil fuels (Popp et al. 2014), while agriculture contributes about 14\% of global anthropogenic GHG emissions and an additional $17 \%$ is contributed through deforestation and conversion of land to agricultural use (Lybbert and Sumner 2012). Over and above its impact on climate change, agriculture itself is affected by those impacts, with projections of additional risks to regional and global food security (Schmidhuber and Tubiello 2007).

Over the past decade, sources of the largest net GHG emissions in Brazil are the land use change and forestry (LULUCF) sectors, especially those associated with conversions of forests and cerrado vegetation to agricultural production. However, the recent report from the Brazilian government indicated a decrease of $85 \%$ in GHG emissions from the LULUCF sector between 2005 and 2012 (MCTI 2014), which could be attributed to the reduction in deforestation in the Amazon region (Nepstad et al. 2014). In 2005, the LULUCF sector contributed $58 \%$ of Brazil's total anthropogenic GHG emissions. Therefore, the observed reduction in deforestation decreased the total national emissions by $41 \%$ (from 2043 to $1203 \mathrm{Tg} \mathrm{CO}_{2}$ eq) in 2012 (MCTI 2014).

Brazil has contributed to the global development and use of bioethanol, which is a feasible option and that can result in negative GHG emissions through replacement of fossil fuels, and a reduction of up to $85 \%$ has been reported (Börjesson 2009). Bioethanol is one of the most widespread biofuels with a global production of 96 billion liters in 2015 (RFA 2016). Trailing USA with a production of 58\% of global ethanol, Brazil is the world's second largest producer (28\%) of ethanol. Thus, Brazil plays an important role in globally supplying the present and future ethanol needs (Manochio et al. 2017). Several food crops that can be used for biofuel production include grains (maize, sorghum, and wheat), sugar crops (sugarcane, sugar beet), starch crops (cassava), and oilseed crops (canola/rape, soybean, and oil palm). Brazil is the world's largest sugarcane producer (Fig. 1), with a cultivated area of 9.1 million hectares in 2016/17 mostly in the south-central (90\%) region of the country (CONAB 2017).

The Brazilian Alcohol Program (Proálcool) was launched in 1975 and was aimed at reducing the reliance on oil imports through production of sugarcane-based ethanol. Nonetheless, the environmental benefits were soon recognized by presenting an avoided emission of $27.5 \mathrm{Tg} \mathrm{CO}$ equivalent in 2003 due to partial substitution of gasoline use in Brazil (Macedo 2005). In addition to these advances, the Brazilian

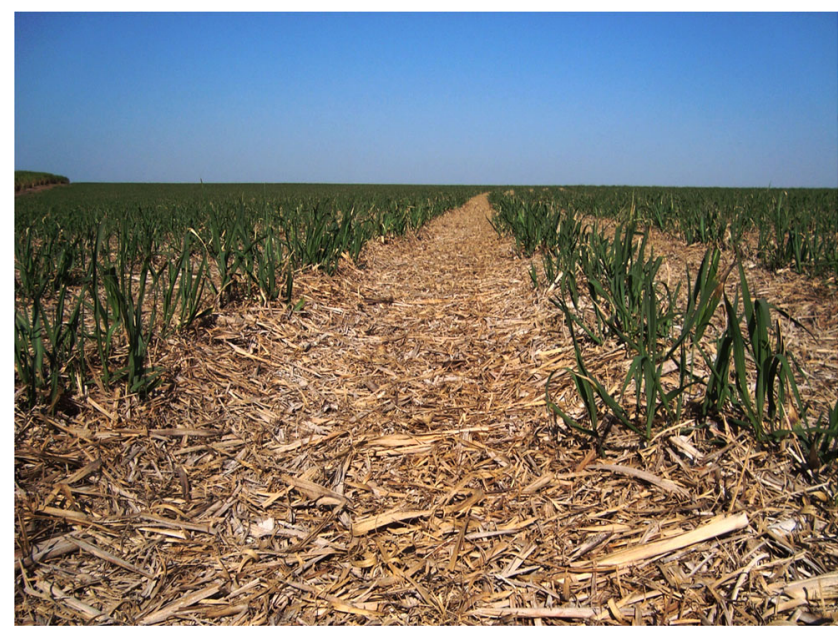

Fig. 1 A recent view of the sugarcane cultivation under green cane management conducted without the preharvest burning in Brazil. The trade-offs between the need to preserve soil health and produce more bioenergy have been the subject of intense discussion, since the adoption of sustainable management practices such as crop residue retention could increase the productivity of agricultural ecosystems and mitigate the effects of climate change through enhanced carbon sequestration. Photographed by J.L.N. Carvalho

government has announced ambitious targets in the last Paris climate agreement within the United Nations Framework Convention on Climate Change: reducing GHG emissions by $43 \%$ below 2005 levels by 2030 (iNDC Brazil 2015). To meet this target, among other strategies, the Brazilian government has recently launched the "RenovaBio" program to boost the share of renewable fuels in its energy mix, with the attendant increase in ethanol production from 28 billion liters per year in 2015 to around 50 billion liters by 2030 (MME 2017).

Despite numerous advantages as a sustainable feedstock for biofuel production, there are growing concerns regarding the potential environmental impacts of expansion of sugarcane cultivation and the attendant land use change, disruption of food supply, GHG emissions from agricultural inputs and farming operations, excessive water use and eutrophication, loss of soil biodiversity, accelerated soil erosion, etc. Further, the avoidance of GHG emissions by biofuels depends on the competing uses of feedstocks and the associated agricultural management practices (Davis et al. 2013). Recent analysis of the energy balance and GHG emissions from alternative options of biofuels created a major controversy and raised concerns about its sustainability (Seabra et al. 2011; Tsao et al. 2011; Macedo et al. 2008; Renouf et al. 2008; Dunn et al. 2013). Therefore, continuous scientific and technological developments are essential to ensuring the sustainability of sugarcane ethanol, especially with regard to sugarcane agricultural sector, which accounts for $81-90 \%$ of total GHG emissions from ethanol production in Brazil (Pereira and Ortega 2010; Seabra et al. 2011). 
Among concern regarding the increase in world's biofuel production is the need for additional land required to meet the future demands of ethanol (Leal et al. 2013b). Indeed, world ethanol production from corn and sugarcane is expected to increase from 80 billion liters to approximately 200 billion liters in 2021 (Goldemberg et al. 2014). Several aspects regarding the ethanol production chain that must be assessed to achieve this target in an environmentally compatible manner include the land use change (Fargione et al. 2008; Lapola et al. 2010), food security versus ethanol production (Tilman et al. 2009), agricultural management practices (Lal 2004), water quality and availability (Hernandes et al. 2014; Filoso et al. 2015), the energy balance (Macedo et al. 2008), and the carbon (C) footprint (Bordonal et al. 2012; Lal 2014). In this context, the sugarcane cultivation has a vast potential to enhance the environmental benefits by optimizing the agricultural production chain (e.g., integrating sugarcane with food production, intensifying pastoral land use, narrowing the yield gaps, increasing $\mathrm{N}$ use efficiency, prohibiting residue burning, and using no-till or reduced tillage) and thereby moderating their local environmental impacts.

Based on the literature review and with focus on the sugarcane agricultural sector, the objective of this article is to address the major sustainability issues associated with the environmental consequences of rapidly expanding sugarcane cultivation in Brazil. Specific objective is to identify knowledge gaps and prioritize future research. Therefore, the goal of this article is to synthesize the existing knowledge on the implications of sugarcane expansion on land use change and its competition with food production, along with the potential opportunities for agricultural intensification. The article also addresses recent advances in the environmental impacts of sugarcane cultivation and identifies opportunities to improve Brazil's sugarcane production chain and enhance its sustainability.

\section{Impact of sugarcane expansion on land use change}

Growing population has aggravated the stress on land and other natural resources to meet the growing demands for food, fiber, fodder, and fuel. The land use changes (LUC) in Brazil for producing soybean and timber and raising cattle have been the main drivers of the deforestation of the Amazon (Nepstad et al. 2014), which had the highest global rate of deforestation in 2005 (MCTI 2010). Even with the largest potential of agricultural expansion in the near future, there has been a $40 \%$ decrease in national GHG emissions since 2005, and a potential cooling of the climate at the local scale through reduction in area of deforestation (Lapola et al. 2013). Public policy interventions in beef and soybean supply chains have contributed to the recent $70 \%$ decline in deforestation in the Brazilian
Amazon, and the target of reducing emission by $90 \%$ in 2018 compared with the baseline rate of 2005 may also be met (Nepstad et al. 2014).

Being the world's top producer of soybeans, coffee, sugar, beef, chicken, dry beans, oranges, and tobacco, Brazil is one of the world's most important agricultural countries. Yet, its agricultural land area in 2016 was merely 78 million hectares out of the total national land area of 851 million hectares (IBGE 2017). Concerns about the sustainability arise from the extent of displacement of food and feed crops by sugarcane and/or deforestation for biofuel feedstock (Walter et al. 2011; Nguyen et al. 2010). Loss of biodiversity, increase in food prices, and GHG emissions from LUC may be significant depending on the specific practices used for production of biofuels (Popp et al. 2014). Indeed, any savings in C from biofuels may be negated by any pressure of sugarcane expansion over native forests or grasslands (Fargione et al. 2008; Searchinger et al. 2008). Nevertheless, assessing the direct LUC to sugarcane plantation during 2000-2009 in southcentral Brazil, Adami et al. (2012) reported that $\sim 96 \%$ of recent expansion has occurred over pastures $(69.7 \%)$, annual crops (e.g., soybean, corn, sorghum, and cotton; 25\%), and citrus $(1.3 \%)$. Corroborating these findings, Sparovek et al. (2009) reported that sugarcane expansion resulted in a significant reduction of pastures during 1996-2006 but did not contribute to direct deforestation in the agricultural region where most of the expansion occurred.

Presently, estimates of the effects of LUC on soil C balance also take into account the $\mathrm{CO}_{2}$ savings from cultivation of the sugarcane. For the 20-year period, Mello et al. (2014) estimated the soil C debt at 21 and $5.7 \mathrm{MgC} \mathrm{ha}^{-1}$ upon conversion of native vegetation and pastures into sugarcane, respectively. With consideration of the ethanol $\mathrm{C}$ offset $(2.7 \mathrm{Mg}$ $\mathrm{C} \mathrm{ha}^{-1}$ year $^{-1}$ ) by displacing the fossil fuels (Fargione et al. 2008), the magnitude of soil $\mathrm{C}$ debts would take 8 and 2 3 years to be offset following the LUC from native vegetation and pastures, respectively. However, most of sugarcane areas in this study were either harvested with burning or this practice had just been stopped for 3 years or less prior to obtaining the soil samples. Therefore, the effects of converting pastures into sugarcane on soil $\mathrm{C}$ debts remain unclear for areas where sugarcane residues are retained on the soil surface upon harvest without burning (green harvest). Recent studies on longterm simulations show that the conversion of pastures into sugarcane with green harvest is associated with soil $\mathrm{C}$ accretion at a rate of $0.16 \mathrm{Mg} \mathrm{C}^{-1}$ year $^{-1}$ (Oliveira et al. 2017a). Furthermore, $15.9 \mathrm{Mg} \mathrm{C}^{-1}$ is also stored annually into sugarcane biomass (Beeharry 2001), and therefore the replacement of the ecosystems containing the lowest biomass $\mathrm{C}$ stocks (e.g., degraded grasslands) by high yielding energy crops (e.g., sugarcane, oil palm) may reduce or even eliminate the payback time of the C debts incurred from LUC (Gibbs et al. 2008). 
Assuming that more than $50 \%$ of the pastureland in Brazil is degraded (Costa and Rehman 1999) and the LUC-induced debt of soil $\mathrm{C}$ depends on the current condition of the pastures (Mello et al. 2014), the effects of direct land use change to sugarcane plantation could lead to indirect climate benefits by cooling the local climate (Loarie et al. 2011) and mitigating GHG emissions (Bordonal et al. 2015). Similar to the expansion of sugarcane over the 2006-2011 period (Fig. 2), converting citrus and natural forests into sugarcane is also inevitable (Bordonal et al. 2015). Indeed, converting degraded pastures into sugarcane plantations is an important strategy to ensure the environmental benefits of sugarcane ethanol for enhancing the $\mathrm{C}$ budget in both soil and the biomass (Fig. 3) (Oliveira et al. 2016; Bordonal et al. 2017). Further, sugarcane expansion reintegrates degraded pasturelands into a more productive system, so that even the slight improvements in soil quality (i.e., increased soil chemical quality) have already been reported when extensive pasture is converted into sugarcane (Cherubin et al. 2016). The soil under sugarcane functioned at $74 \%$ of their potential capacity compared with those under extensive pasture at $70 \%$. While the expansion of sugarcane on extensive pastures leads to slight but significant improvements in soil quality, there can be a significant loss in soil biodiversity by sugarcane expansion from pasturelands, in which the diversity and abundance of soil macrofauna groups have been reduced by 39 and $89 \%$, respectively (Franco et al. 2016). These data validate the importance of the advances in management in agricultural systems for reducing the risks of future decline in soil quality and for improving biodiversity in sugarcane fields.

The reality of rapidly expanded sugarcane crop across south-central Brazil also raises concerns regarding the indirect land use change (iLUC), in which the agricultural land use

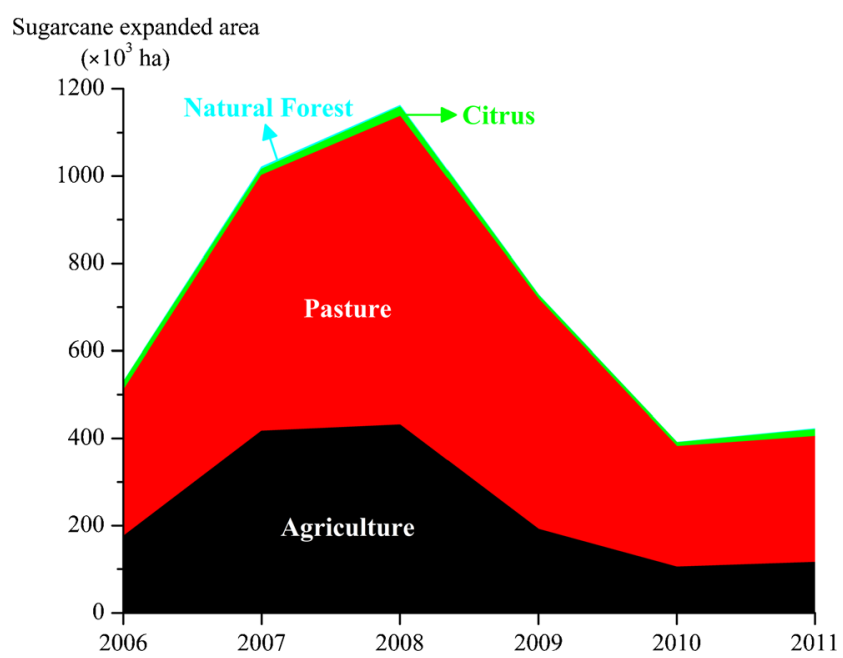

Fig. 2 Dynamic of direct land use change of recently sugarcane expansion over diverse agricultural uses (e.g., annual crops, pastures, citrus, and natural forest) in south-central Brazil during 2006-2011. Adapted from Bordonal et al. (2015)

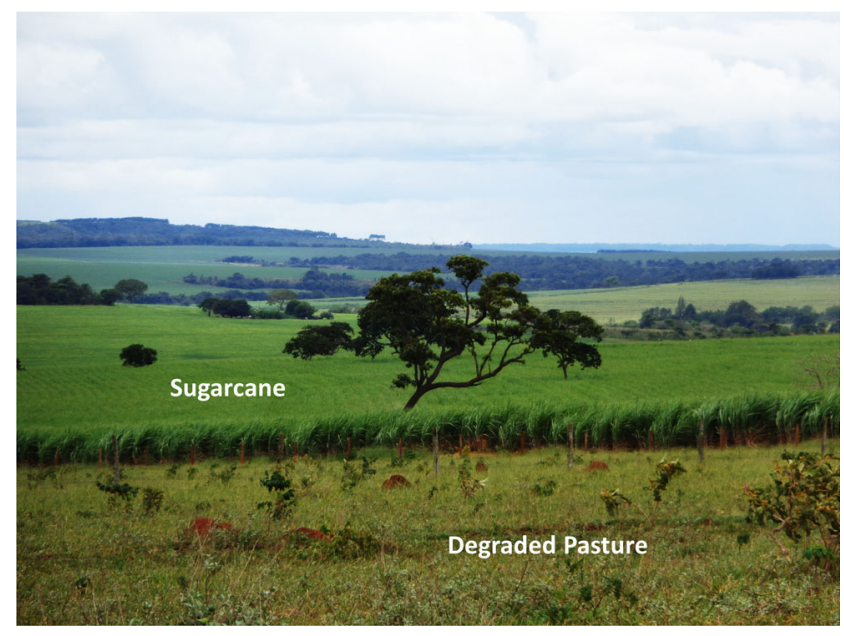

Fig. 3 Extensive pasture and sugarcane agrosystems represent the most intense land use change associated with sugarcane expansion in southcentral Brazil. The typical pasture management in Brazilian tropical soils is characterized by the pasture degradation due to low grass productivity and inadequate grazing management. Note the sparse vegetation cover. Photographed by M.R. Cherubin

type converted into sugarcane plantation is displaced elsewhere. However, the magnitude of iLUC to replace either pastoral or arable lands displaced by biofuel expansion in Brazil is highly uncertain (Searchinger et al. 2008; Verstegen et al. 2016) and poorly understood (Zilberman 2017), mostly by pushing rangelands frontier into the Amazon and Cerrado biomes (Lapola et al. 2010). Zilberman (2017) suggested that these estimates may be seriously distorted not only because iLUC is uncertain and estimates vary substantially but also because it fails to capture the basic features of agricultural industries and land resources. Further, existing methodologies for quantifying iLUC caused by sugarcane expansion and its impact on total GHG emission and other environmental issues are still controversial due to the lack of empirical data and of the solid model representations of Brazilian land use (Sparovek et al. 2009).

Principal reasons of the small iLUC include livestock intensification, ample availability of land, improvements in agronomic yield, and expansion of sugarcane over low intensity pastures (Walter et al. 2014). Another important point arises from the expansion of sugarcane into regions with higher potential for agricultural productivity, where iLUC effects associated with sugarcane expansion may have been attenuated by higher productivity in sugarcane production in Brazil (Ferreira Filho and Horridge 2014). Corroborating these assumptions, Lapola et al. (2013) have also shown that decoupling of deforestation and agricultural expansion in the Amazon has occurred because of the convergence of several factors such as internal market regulations, creation of more protected areas, command-and-control crackdown on illegal deforestation, and credit barriers imposed by the federal government on municipal counties in deforestation frontiers. 
Regardless of the magnitude of iLUC, it is important to identify the strategies that reduce the risk of iLUC emissions. Integration of sugarcane and livestock sectors can improve land use efficiency in Brazil, since more intensive cropping systems can maintain, or even increase food production while reducing the impacts of direct and indirect LUC from agriculture expansion (Egeskog et al. 2011). Establishing sugarcane plantation on marginal and degraded lands with simultaneous pasture intensification is also an important strategy to avoid iLUC effects of ethanol production (Lal 2014; Egeskog et al. 2014). The intensification and restoration of degraded pastures for livestock sector lead to higher meat yield and reduce the land occupation factor, thereby avoiding further deforestation and providing additional land for other agricultural uses such as sugarcane bioenergy systems (De Figueiredo et al. 2017). Incentives through public policies and technology development are needed to ensure the expansion of sugarcane towards a sustainable path, and aimed at meeting the global demand for both food and biofuel feedstocks while avoiding the undesirable LUC (Tilman et al. 2009).

\section{Land competition versus food production}

Land availability and competition between supply of energy and other commodities (e.g., food, sugar, milk, and grain) have global implications, especially if biofuels can be produced in harmony with other needs, without jeopardizing food production, $\mathrm{C}$ reservoirs, and biodiversity (Valentine et al. 2012). Under certain conditions, modern bioenergy can even be an important strategy of advancing food security in some countries. For example, biofuels could be produced from inedible plants that grow on land that is not well suited for growing food (Lynd and Woods 2011). In contrast, indirect effects of land use conversion and cultivation of food-based biofuel crops may impact the food prices and determine the availability/access of food for the poorest (Searchinger et al. 2015). While some argue that biofuel production may have a large impact on global food prices (Chakravorty et al. 2009), there are others who argue against it and state that $\sim 88 \%$ of the growth in food prices is triggered by factors other than biofuels (Timilsina and Shrestha 2011).

Livestock production is the largest anthropic use of land resources worldwide, which includes grazing land and cropland dedicated to feed production. Thus, it is pertinent to analyze the area devoted to produce ethanol from sugarcane with the availability of land. In 2007, Brazil had a total cultivable land area of 354.8 million hectares, as estimated by considering the areas allocated to forestry, native forests, natural and planted pastures, and perennial and annual crops. Of the total cultivable land, $48.6 \%$ (172.3 million hectares) is under pastures and $21.6 \%$ (76.7 million hectares) is cultivated for soybean $(5.8 \%)$, corn $(3.9 \%)$, and other crops (8.5\%). Energy crop (i.e., sugarcane for ethanol) represents $1.0 \%$ of the Brazilian cultivable lands and $4.4 \%$ of the cultivated area, which is relatively small compared to the allocated area for other commodities (e.g., corn and soybean). Yet, potential of agricultural expansion in Brazil is large since an additional area of 105.8 million hectares $(29.8 \%)$ remains available (Fig. 4; Goldemberg and Guardabassi 2010).

While the production and use of ethanol in Brazil increased substantially between 2005 and 2015, a large growth has also occurred in food production and in the expansion of land area (Gauder et al. 2011). Soybeans, corn, sugarcane, beans, and rice are the most important annual crops, occupying $\sim 90 \%$ of the cultivated area in Brazil. Whereas the area under soybean increased significantly ( 10 million hectares) during 2005 2016, those under sugarcane and corn increased at a lower rate (Fig. 5; IBGE 2017). The fact that little changes occurred in other types of land uses indicates little if any competition for land between food and sugarcane, and it adversely affects neither food production nor the commodity prices. Even biofuels perceived as the main driver of increase in food prices and widespread hunger among the poor around the world, Brazilian ethanol production from sugarcane neither has been a serious problem with regard to the spike in international food prices in 2008 nor has a negative effect on poverty (Ferrera Filho 2013).

The strong expansion of sugarcane agricultural frontier on degraded pastures (Fig. 2), the increased yields of food crops and livestock intensification between 1995 and 2015 have attenuated land competition between food and sugarcane plantation (Nogueira and Capaz 2013). For instance, the Brazilian cattle herd increased by $251 \%$ between 1960 and 2010, but the stocking rate increased from 0.47 to 1.2 head ha ${ }^{-1}$ (McManus et al. 2016). Additionally, an important strategy to avoid further deforestation has been the land use program (e.g., Agro-ecological Zoning) launched by the national government in 2009 for guiding ethanol production on a sustainable pathway and for respecting environmental boundaries by avoiding the expansion and cultivation of sugarcane in areas under native vegetation and devoted to foodbased crops. By classifying and identifying regions with the highest potential of sugarcane yield, 64 million hectares is found to be suitable for sugarcane plantation. Of this, 53\% (34 million hectares) is marginal land and degraded pastures (Manzatto et al. 2009), which would be enough to meet the projected biofuel and food demands necessary for well-being of the future generations.

\subsection{Opportunities for agricultural intensification}

The projected climate change may affect agricultural production in several ways. Thus, the conventional agriculture is in dire need of sustainable intensification to protect ecosystem $\mathrm{C}$ pools and biodiversity. Rather than expanding cultivation into 
Fig. 4 Total of tillable lands (million hectares-Mha) and types of land use in 2007. Adapted from Goldemberg and Guardabassi (2010)
Total of tillable lands (2007) - 354.8 Mha

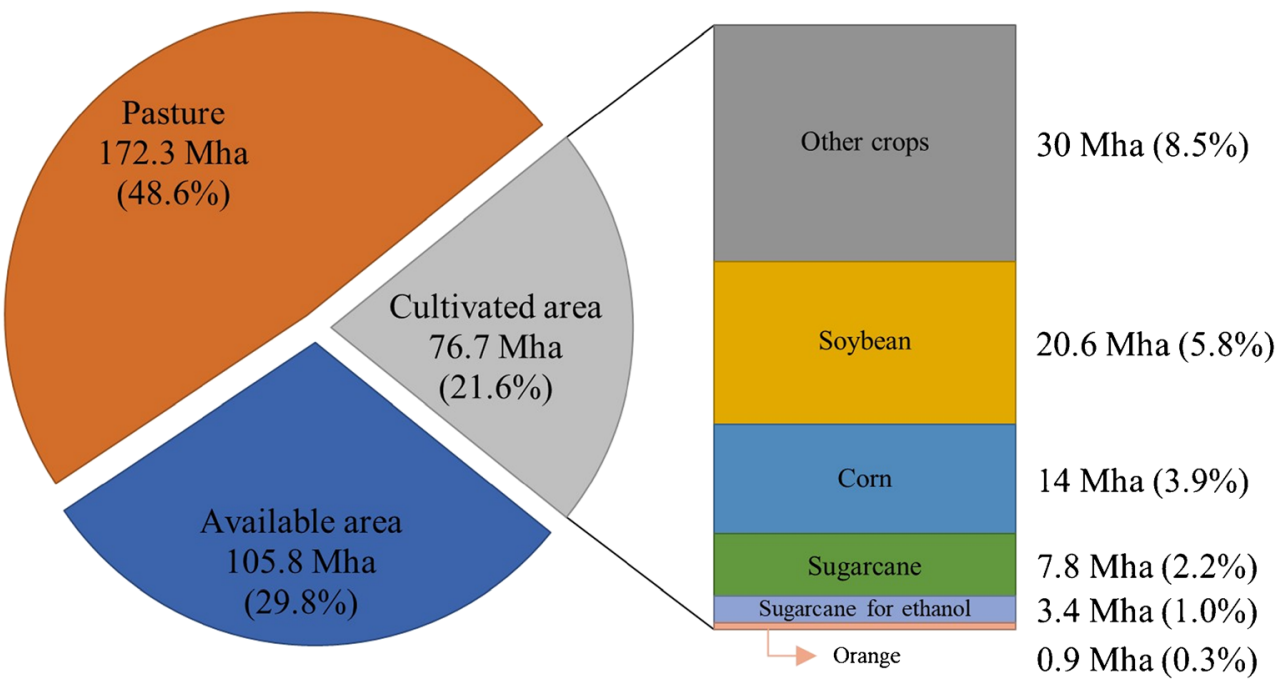

new lands, the key strategy of sustainable intensification is to produce more from the same area and with fewer resources, while minimizing the negative externalities. In this context, there is a potential to produce $60-100 \%$ additional food by minimizing losses and waste (Lal 2013). Closing yield gaps, adopting systems of sustainable management (i.e., improved pasturelands, agroforestry systems, conservation agriculture), restoring soil organic carbon, adopting precision application of inputs, using legumes in the rotation cycle, and intercropping systems are among the several opportunities that must be prioritized and explored (Tilman et al. 2002; Lal 2006; Johnston et al. 2011).

Through high-yielding technologies (e.g., genetic engineering, advanced hybrids, new biorefinery technologies, and new cultivation practices), Brazilian capacity for ethanol production could also quadruple without major implications to land use (Mathews 2007). The yield gap in sugarcane in
Brazil is $76 \mathrm{Mg} \mathrm{ha}^{-1}$, because of the low national average yield of $72 \mathrm{Mg} \mathrm{ha}^{-1}$ (CONAB 2017) compared with the attainable yield of $148 \mathrm{Mg} \mathrm{ha}^{-1}$ (Carvalho-Netto et al. 2014). Marin et al. (2016) also reported that the current national average yield ( $82 \mathrm{Mg} \mathrm{ha}^{-1}$ ) is $62 \%$ of the potential yield (134 $\mathrm{Mg} \mathrm{ha}^{-1}$ ) under dryland conditions. Narrowing the exploitable yield gap to $80 \%$ of the potential yield is the key strategy of meeting the projected sugarcane demand by 2024 , with an $18 \%$ reduction in sugarcane area for the lowdemand scenario or a $13 \%$ expansion for the high-demand scenario (Marin et al. 2016).

In Brazil, a large proportion of agricultural land is under pastures ( 172.3 million hectares). However, increasing demand for food, fiber, and energy production has necessitated conversion of additional land to crop production (Barretto et al. 2013). Because of extensive practices (e.g., traditional management and low adoption of improved technology), the
Fig. 5 Temporal dynamics associated to land use with the main temporary crops and evolution of sugarcane planted area across Brazil during 20052016. Adapted from IBGE (2017)

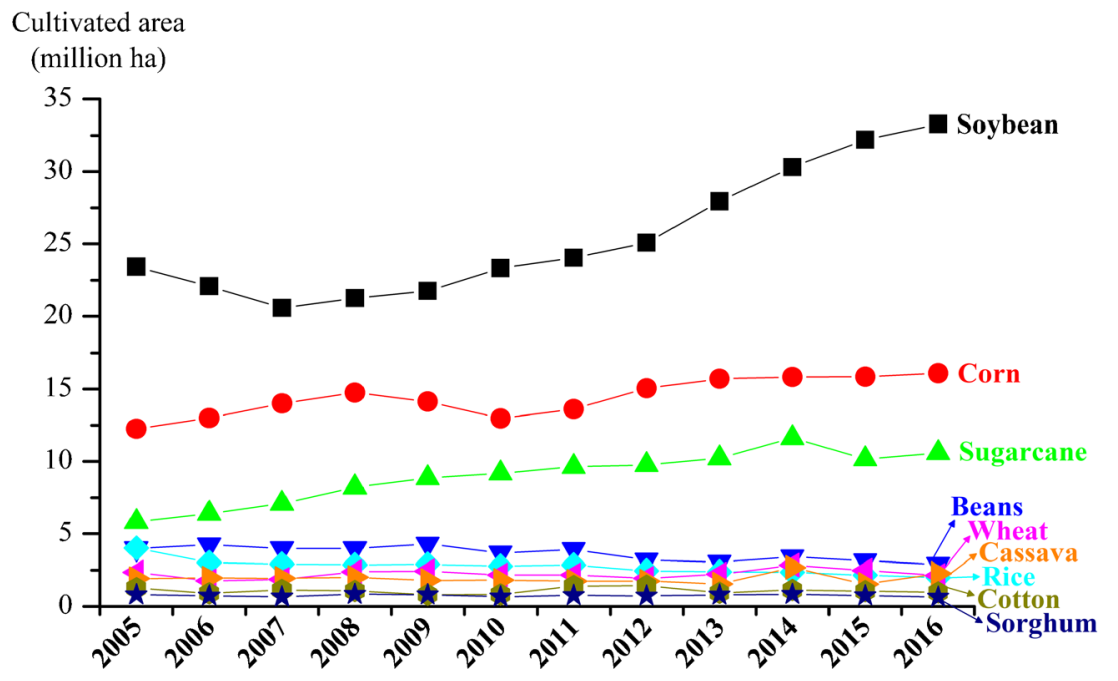


productivity of Brazilian pasturelands is $32-34 \%$ of its potential. Thus, an improvement to $49-52 \%$ of the potential would free up some land to meet demands for crops, meat, wood products, and biofuels without the need for any new deforestation until at least 2040. This strategy would also avoid emission of up to $14.3 \mathrm{Gt} \mathrm{CO}_{2}$ eq per annum (Strassburg et al. 2014). Important strategies of improving productivity include assessing the potential for agricultural intensification under pasture, avoiding further deforestation, and reducing the associated GHG emissions.

Livestock intensification in Brazil is a distant reality. Thus, it is justified to assume that $\sim 60-75$ million hectares of degraded pastures could be reclaimed to provide more areas for agriculture and bioenergy in the near future (Nogueira and Capaz 2013). Initiatives such as crop-livestock integration and pasture improvement could release up to 41 million hectares of land from pasture to other agricultural uses. Through increasing the pasture carrying capacity in Brazil from 1.09 to 1.53 animals $\mathrm{ha}^{-1}$, expansion of sugarcane for biofuel on pastureland would have no adverse impact on any of its natural ecosystems (Goldemberg et al. 2014). Walter et al. (2014) observed that an improvement of $10 \%$ in the current pasture carrying capacity of just one more head per hectare would release 20 million hectares for agricultural expansion without any deforestation. The land area thus saved is enough to meet the national land demand of 22 million hectares needed for global production of 300 billion liters of ethanol demand by 2030, based on a combination of first- and second-generation technologies in Brazil (Leal et al. 2013b).

There exists a large scope for productivity improvements in livestock sector through the use of surplus bagasse as animal feed, which could reduce GHG emissions associated with meat/dairy production and attenuate the possible effects of LUC induced by sugarcane expansion on pastures (Egeskog et al. 2014). Integrated ethanol/livestock systems reduce the risk of displacement and increase the land use efficiency in meat/dairy production (Egeskog et al. 2011). Several sugarcane-processing byproducts (e.g., hydrolyzed bagasse/ treated bagasse, raw bagasse, sugarcane straw, liquid yeast, dry yeast, molasses, and cane tops) can be combined or treated to feed cattle, in which different pretreatment alternatives can be used to increase digestibility and nutritional value of animal feed (Dale et al. 2010). However, the use of sugarcane byproducts to feed cattle is currently a non-conventional business option, and additional research is needed on this topic.

Better economic and environmental developments have also been observed in Brazil with incorporation of sunn hemp (Crotalaria juncea) in rotation with sugarcane (Bordonal et al. 2012; Chagas et al. 2016). However, leguminous cover crops (e.g., peanut, soybean and sunn hemp) are typically grown during the fallow period of renovation of sugarcane fields every 5 or 6 years. Another opportunity for addressing the need for both food and biofuel productions is through adoption of the intercropping systems, in which food and energy crops are grown simultaneously (Malezieux et al. 2009). A large proportion of the rainfall, soil nutrients, and solar energy between the rows remain unexploited during the initial stages of sugarcane growth immediately after the harvest (e.g., 90-120 days). Because sugarcane takes 2 to 3 months to get established, any short-duration inter row crops can be grown during this period (Teshome et al. 2015).

In India, Singh et al. (2008) observed that sugarcane-based intercropping system improved profitability and resulted in higher sugarcane yield than that under sole stand. In China, Yang et al. (2013) concluded that sugarcane-soybean intercropping is an optimum agricultural system for land use efficiency, nitrogen use efficiency, crop yield, production cost, and environment protection. Therefore, intercropping with sugarcane could be agronomically advantageous and provide additional revenue (Teshome et al. 2015). Intercropping legumes or grain crops between sugarcane ratoon rows is an uncommon practice in Brazil and is poorly understood from an agronomic and environmental point of view (Bolonhezi et al. 2010). Practical issues and agricultural management are the key barriers to be overcome, and a concentrated and well-funded research and extension efforts are required to elucidate intercropping systems in sugarcane areas as a feasible opportunity for agricultural intensification and additional food production.

\section{Sugarcane production-related impacts}

Bioenergy crops have been proposed as an alternative to increase global sustainability while also meeting the energy demand (Koçar and Civaş 2013). Several studies have highlighted the environmental benefits of sugarcane ethanol as an effective option to mitigate GHG emissions when compared to other biofuel feedstocks (Seabra et al. 2011; Goldemberg and Guardabassi 2010; Muñoz et al. 2014). Based on studies of life cycle assessment, Table 1 summarizes the commonly evaluated parameters (e.g., energy balance, GHG savings, biofuel yield, and water footprint) and compares the main energy crops (e.g., corn, sugarcane, wheat, sugar beet, and sorghum) used to produce the world's bioethanol.

The sugarcane-based ethanol is reportedly the most effective option for all mentioned parameters, with the highest energy balance (9.1) in comparison with corn (1.4), wheat (5.2), sugar beet (2.0), and sorghum (2.8). Thus, ethanol from sugarcane reduces emissions of GHGs by $85 \%$ through substitution of fossil fuels as compared with emission avoidance of $30 \%$ for corn, $45 \%$ for sugar beet, $53 \%$ for sorghum, and $64 \%$ for wheat. The use of biomass as biofuel for power generation during the industrial phase is the major factor of achieving desired emission reductions (García et al. 2011). Sugarcane-based ethanol $\left(\mathrm{L} \mathrm{ha}^{-1}\right)$ has higher average yield 
Table 1 Average parameters associated with the main feedstock sources used for the global ethanol production

\begin{tabular}{lllll}
\hline Feedstock & Energy balance* & GHG savings** $(\%)$ & Fuel yield (L ha $\left.{ }^{-1}\right)$ & $\begin{array}{c}\text { Water footprint*** (L of } \\
\text { water per L of ethanol) }\end{array}$ \\
\hline Corn (Zea mays L.) & $1.4^{\mathrm{a}, \mathrm{b}}$ & $30^{\mathrm{a}}$ & $4010^{\mathrm{a}, \mathrm{j}, \mathrm{k}}$ & $2486^{\mathrm{n}, \mathrm{o}}$ \\
Sugarcane (Saccharum spp.) & $9.1^{\mathrm{c}, \mathrm{d}}$ & $85^{\mathrm{a}, \mathrm{d}, \mathrm{g}, \mathrm{h}}$ & $6900^{\mathrm{c}, \mathrm{d}, \mathrm{g}, \mathrm{j}}$ & $2245^{\mathrm{n}, \mathrm{o}}$ \\
Wheat (Triticum) & $5.2^{\mathrm{b}}$ & $64^{\mathrm{i}}$ & $2450^{1}$ & $4339^{\mathrm{n}, \mathrm{o}}$ \\
Sugar beet (Beta vulgaris) & $2.0^{\mathrm{b}}$ & $45^{\mathrm{a}, \mathrm{h}}$ & $5250^{\mathrm{a}, \mathrm{l}}$ & $1176^{\mathrm{n}, \mathrm{o}}$ \\
Sorghum (Sorghum bicolor L. Moench) & $2.8^{\mathrm{e}}$ & $53^{\mathrm{e}}$ & $2990^{\mathrm{m}}$ & $8317^{\mathrm{n}, \mathrm{o}}$
\end{tabular}

Mean values were computed according to the arithmetic average of the data found in the literature (superscript letters) for each assessed parameter. Otherwise, absolute values were considered when there is only one available data

*Ratio of energy output in a liter of ethanol over the fossil fuel energy input required to produce it

**Avoided greenhouse gas (GHG) emission through substitution of fossil fuels

***Water footprints of bioenergy crops were estimated considering the green and blue components

${ }^{\mathrm{a}}$ Goldemberg and Guardabassi (2010), ${ }^{\mathrm{b}}$ von Blottnitz and Curran (2007), ${ }^{\mathrm{c}}$ Boddey et al. (2008), ${ }^{\mathrm{d}}$ Macedo et al. (2008), ${ }^{\mathrm{e}}$ Wortmann et al. (2010),

${ }^{\mathrm{f}}$ Börjesson (2009), ${ }^{\mathrm{g}}$ Seabra et al. (2011), ${ }^{\mathrm{h}}$ Smeets et al. (2006), ${ }^{\mathrm{i}}$ Larson (2006), ${ }^{\mathrm{j}}$ Balat and Balat (2009), ${ }^{\mathrm{k}}$ Dunn et al. (2013), ${ }^{1}$ Rocha et al. (2014),

${ }^{\mathrm{m}}$ Vinutha et al. (2014), ${ }^{\mathrm{n}}$ Gerbens-Leenes et al. (2009), ${ }^{\circ}$ Mekonnen and Hoekstra (2011)

of 6900 compared with 5250 from sugar beet, 4010 from corn, 2990 from sorghum, and 2450 from wheat. The water footprint (liter of water per liter of ethanol) of ethanol from sugarcane, the second most efficient crop, is 2245 compared with that of 1176 for sugar beet, the most efficient crop. In comparison, the water footprint of ethanol is 8317 from sorghum, 4339 from wheat, and 2486 from corn.

While those benefits of ethanol from sugarcane have been widely reported (Goldemberg 2007; Farrell et al. 2006), there are also reports negating the desired mitigation through biofuel production (Searchinger et al. 2008; Lapola et al. 2010). Important explanations of these apparent contradictions include the use of diverse methodologies and assumptions, and differences in system boundaries, emission factors, agricultural inputs, geography, land use change, and in allocating emissions to coproducts, etc. (Davis et al. 2009; García et al. 2011). Major trends on sustainability of sugarcane production systems, as well as management strategies to overcome their related impacts, are discussed in the following subsections, in order to provide easily available information regarding the current status of agricultural production and the advances made thus far.

\subsection{Green mechanized harvesting and tillage practices}

In addition to the release of soot, GHGs and particulate matter into the atmosphere, burning of residues prior to harvest has also significant detrimental effects on human health (Tsao et al. 2011). Several studies have reported a correlation between emissions of particulate matter from sugarcane burning and diseases such as asthma, respiratory problems, lung cancer, and hypertension hospital admissions (Silveira et al. 2013; Cançado et al. 2006; Arbex et al. 2007). Furthermore, sugarcane burning is responsible for an emission of $941 \mathrm{~kg} \mathrm{CO}_{2} \mathrm{eq} \mathrm{ha}^{-1}$ year $^{-1}$, which corresponds to $30.3 \%$ of total GHG emission related to sugarcane agricultural production (De Figueiredo and $\mathrm{La}$ Scala Jr. 2011). In the last decade, there has been a gradual decrease from 61 to $6 \%$ (2.3 million hectares) in areas under sugarcane burning in south-central Brazil (Fig. 6), especially in the São Paulo state with the implementation of legislation to banish the burning practice (Aguiar et al. 2011). Capaz et al. (2013) observed a 39.3\% reduction in GHG emissions (i.e., from 1.015 to $0.639 \mathrm{Mg} \mathrm{CO}_{2} \mathrm{eq} \mathrm{ha}^{-1}$ ) through conversion from burned to green harvest during 1990-2009 in São Paulo. Likewise, a shift on harvest management had an improvement in more than $90 \%$ on human health impacts, and the global warming potential and black $\mathrm{C}$ emissions are expected to be $70 \%$ and 216 times lower with complete mechanization in the future, respectively (Galdos et al. 2013).

Non-burning harvesting is well known in the scientific literature as a win-win strategy because of its benefits involving agronomic and environmental aspects. However, in the green harvest system, the higher levels of soil compaction have been recognized as the main issue in traditional sugarcane cropping systems in Brazil because of heavy and intense traffic during mechanical harvest and transport (Otto et al. 2011; Souza et al. 2014). A substantial drop in sugarcane yield has been observed since 2008, when the mechanization (e.g., harvest and planting operations) was intensified (Fig. 7). Best management practices are and will continue to be crucial to overcome this issue, including the retention of straw in sugarcane fields, inclusion of crop rotation within the 


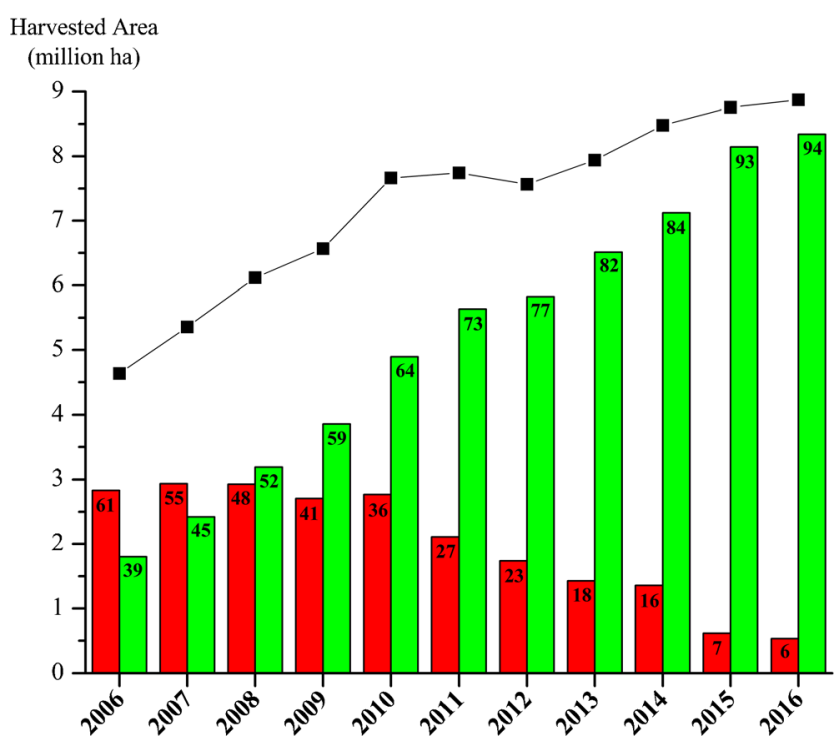

Fig. 6 Total harvested area (black line) in south-central Brazil and evolution (in percentage) of the type of harvest during 2006-2016: manual burned (red bars) versus green mechanized (green bars). Data adapted from Bordonal et al. (2015), CONAB (2017), and UNICA (2017)

sugarcane cropping cycle, and adoption of no-till or reduced tillage. These management strategies are essential to increasing sugarcane yields to $100 \mathrm{Mg} \mathrm{ha}^{-1}$. Yet, the high degree of harvest mechanization increases diesel consumption and its contribution on the overall GHG emissions. Brazilian sugarcane sector was an important contributor to GHG emissions ( $40 \%$ in 2009$)$ from the high consumption of diesel in the mechanized harvest (Capaz et al. 2013). The replacement of diesel by a renewable fuel (e.g., biodiesel from vegetable oils and fuel ethanol) and higher efficiency of machinery and transportation vehicles are some options that can reduce the associated GHG emissions (García et al. 2011; Ometto et al. 2009).

Sugarcane has an average yield of $\sim 80 \mathrm{Mg} \mathrm{ha}^{-1}$, of which $14 \mathrm{Mg} \mathrm{ha}^{-1}$ of dry matter is currently left on the soil surface after each harvest (De Figueiredo and La Scala Jr. 2011). However, the amount of biomass retained varies with crop cycle, variety, site, soil fertility, etc. (Menandro et al. 2017). From an agronomic point of view, the practice of maintaining the sugarcane straw on the soil surface brings numerous ecosystem services in the long term, including lower variation in soil temperatures, better water infiltration and availability due to smaller evapotranspiration, effective weed control, and protection against soil erosion (Carvalho et al. 2017a). The latter is a very important issue in sugarcane fields. Soil covered with sugarcane straw reduces soil erosion by dissipating the kinetic energy of raindrops, decreasing the flow velocity, and increasing the depth of the water layer on the soil surface (Martins Filho et al. 2009). Soil erosion losses can range from 16 to $150 \mathrm{Mg} \mathrm{ha}^{-1}$ year $^{-1}$ and strongly depend on the terrain slope, rainfall, soil type, and soil coverage (Hartemink 2008). Martins Filho et al. (2009) reported that the maintenance of 50 and $100 \%$ of the sugarcane straw on the soil surface in comparison with a bare soil reduced soil ersion by 68 and $89 \%$, respectively. These authors concluded that erosion losses in sugarcane areas may decrease exponentially with increase in soil cover, especially with straw coverage equal to or more than $7 \mathrm{Mg} \mathrm{ha}^{-1}$. In this context, the removal of high rates of sugarcane straw for other purposes may aggravate erosion losses and compromise soil quality in sugarcane fields of Brazil and elsewhere (Carvalho et al. 2017a).
Fig. 7 Reported annual sugarcane production (black bars) and evolution of cultivated area (gray bars), including average yields of sugarcane (red line) in Brazil between 1975 and 2017. After 2008 crop season, the intensive mechanization of sugarcane clearly shows the impacts of soil compaction and degradation due to the traffic of large and heavy agricultural machines associated with management and harvest operations. Data acquired from FAOSTAT (2017), IBGE (2017), and CONAB (2017)

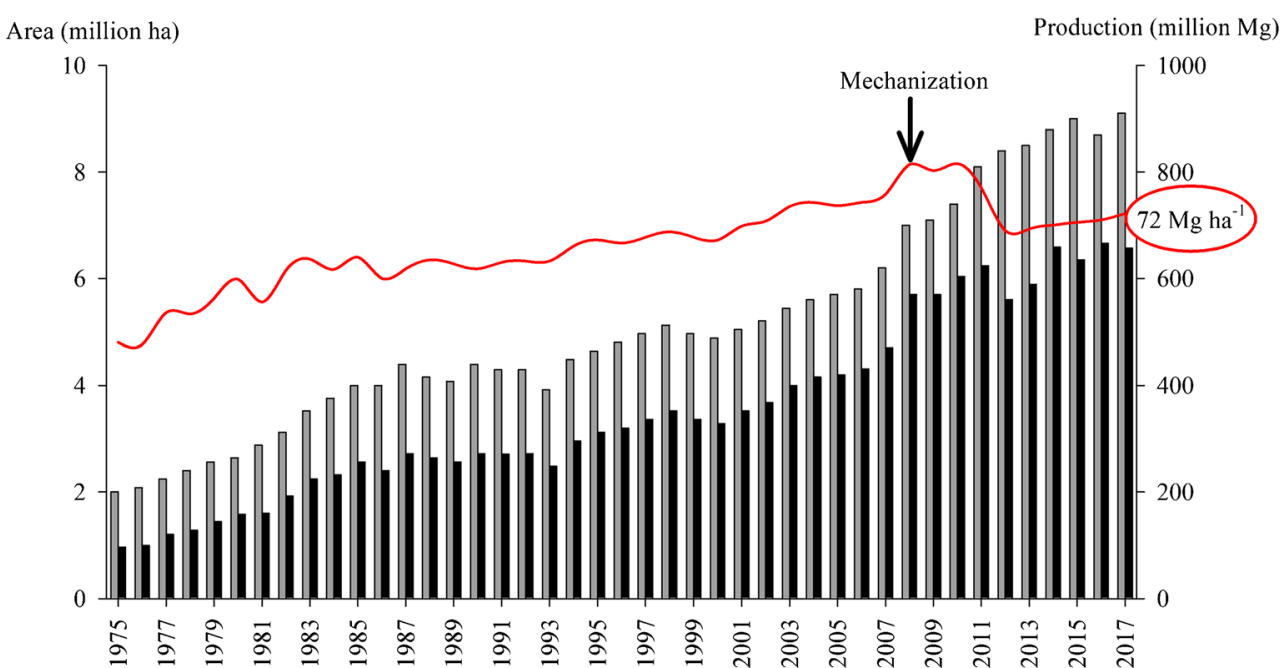


However, some adverse effects have also been observed with the maintenance of large amount of straw in some specific edaphoclimatic conditions, including difficulties in the mechanical cultivation (Magalhães et al. 2012), increased risk of fire (Rossetto et al. 2008), and reduction in the initial tillering of sugarcane (Aquino et al. 2017). Furthermore, straw mulching can create an ideal microclimate (mainly temperature and humidity) for the development of pest and disease infestations (Dinardo-Miranda and Fracasso 2013; Hassuani et al. 2005), which could adversely affect crop yield and increase production costs. In some cases, especially in the cooler temperate regions, maintaining straw on the soil can hinder the ratoon sprouting, resulting in gaps in the stand and reducing the sugarcane yields (Campos et al. 2010; Ramburan and Nxumalo 2017). On the other hand, straw retention in warmer climates has resulted in higher yields by conserving soil moisture and decreasing soil temperature (Aquino et al. 2017).

Elimination of straw burning in sugarcane fields along with efficient use of crop/industrial residues (e.g., sugarcane straw, filtercake, and vinasse) and, mainly, high level of electricity generation exported to the grid could reduce the net ethanol-related emissions to zero by 2020 (Seabra et al. 2011), attaining the energy balance ratio of 11.6 compared with the present value of 9.1 (Table 1; Macedo et al. 2008). With the switch from burned to green harvesting, renewable energy ratio improved from 7.0 in 2002 to 9.4 in 2009 (Chum et al. 2014). Despite the large energy potential associated with the sugarcane straw, additional efforts should be made to establish an appropriate technique to harness such potential (Lisboa et al. 2017).

In the short term, the combustion of sugarcane straw in boilers for bioelectricity generation is likely to be the main application. If $40-50 \%$ of the straw available in the field is used in co-combustion with bagasse, the total electricity surplus from the sugarcane mills can be as much as 468$670 \mathrm{MJ} \mathrm{Mg}^{-1}$ (130-186 $\mathrm{kWh} \mathrm{Mg}^{-1}$ ) of cane (Seabra et al. 2011), indicating an additional potential to be explored as a renewable bioenergy generation. However, a lot of controversy still remains regarding the removal/retention of sugarcane straw on soil after harvest, since it can be used to produce either electricity or second-generation ethanol, and/or could be left in the field to improve soil productivity (Silva et al. 2014; Carvalho et al. 2017a). These aspects should be addressed through further research in order to minimize adverse impact on agricultural sustainability (e.g., soil erosion, nutrients recycling, soil carbon storage, and soil water availability) while still providing biomass-based energy (Leal et al. 2013a).

Systematic removal of straw for ethanol and/or electricity purposes may increase soil $\mathrm{CO}_{2}-\mathrm{C}$ emission (De Figueiredo et al. 2015; Moitinho et al. 2013) and reduce soil organic matter content (Bessou et al. 2011). A positive correlation between the maintenance of sugarcane straw and the soil $\mathrm{C}$ accretion has been reported by several studies (Galdos et al. 2009; Cerri et al. 2011; Pinheiro et al. 2010; Carvalho et al. 2017b). La Scala Jr. et al. (2012) reported a mean rate of soil C accretion from 1.02 to $1.87 \mathrm{Mg} \mathrm{C}^{-1}$ year $^{-1}$ in sugarcane fields under green cane management. These variations in sequestration rate may be attributed to differences in soil texture (e.g., sandy or clay soils), the time since adoption of the green harvest system (Cerri et al. 2011), and the soil management during the sugarcane-replanting period (De Figueiredo et al. 2015). Above all, soil C sequestration may increase crop yields by enhancing soil functions and properties related to the accretion of soil organic matter (Delgado et al. 2011). For instance, soil structure and aggregate formation would increase soil fertility (e.g., cation exchange capacity) and water holding capacity under green cane management through soil coverage upon harvest without burning (Souza et al. 2012; De Luca et al. 2008).

Although the conversion from burned to green harvest has a vast potential to increase soil $\mathrm{C}$ stocks, most of the accumulated $\mathrm{C}$ during the sugarcane cycle can be lost as $\mathrm{CO}_{2}-\mathrm{C}$ emission after soil disturbance during the replanting operations, which are performed once every 5 or 6 years (De Figueiredo et al. 2015). Silva-Olaya et al. (2013) reported that up to $3.5 \mathrm{Mg} \mathrm{CO}_{2} \mathrm{ha}^{-1}$ could be released after tillage of soil in Brazilian sugarcane fields. Cerri et al. (2011) concluded that the lowest $\mathrm{C}$ accumulation rates are observed in fields where soil disturbance and sugarcane replanting were the most recent $(<2$ years), indicating that part of the $\mathrm{C}$ accumulated over the crop cycle was lost during this process. Tillage disrupts soil aggregate and exposes the protected organic matter to microbial activity and consequently a decay of soil organic matter, which increases $\mathrm{CO}_{2}-\mathrm{C}$ emissions to the atmosphere (Six et al. 1999; $\mathrm{La}$ Scala Jr. et al. 2008). Moreover, tillage operations improve conditions for decomposition of soil organic matter because it temporarily reduces soil compaction, increases soil porosity, improves aeration and oxygenation, and increases soil temperature (La Scala Jr. et al. 2006).

New management practices (e.g., reduced tillage during the sugarcane-replanting period) could reduce decomposition of soil organic matter and increase soil $\mathrm{C}$ accumulation. La Scala Jr. et al. (2006) observed that adoption of no-till reduced the $\mathrm{CO}_{2}$ emissions by $8.4 \mathrm{Mg} \mathrm{ha}^{-1}$ compared to conventional tillage practices. In a 7-year study, Segnini et al. (2013) isolated the impacts of the maintenance of straw on soil surface versus tillage operations during sugarcane renovation. Adoption of green cane and conventional tillage resulted in $\mathrm{C}$ retention rates of $0.67 \mathrm{Mg} \mathrm{ha}^{-1}$ year $^{-1}$, while the adoption of green cane and no-till accumulated $1.63 \mathrm{Mg} \mathrm{C} \mathrm{ha}^{-1}$ year $^{-1}$. Maintaining the sugarcane straw on the soil under no-till is, therefore, a sustainable management option to be considered during the sugarcane-replanting period. Furthermore, the adoption of no-till reduces the numbers of tillage operations, 
decreases $\mathrm{CO}_{2}$ emission by fuel consumption, and indirectly mitigates GHG emissions in agricultural production (West and Marland 2002; Antle and Ogle 2012), beyond other aspects such as air and water quality impacts (Smith et al. 2007). Importantly, no-till or reduced tillage is one of the strategies contributing to global food security and the protection of soils, and thus to climate change adaptation through building agricultural systems that are more resilient to climate and weather variability (Powlson et al. 2014).

Despite many benefits, no-till system is not yet widely used in sugarcane fields in Brazil. Derpsch et al. (2014) opined that no-till is a conservation farming system, in which seeds are placed into untilled soil by opening a narrow furrow with only a sufficient width and depth to obtain proper seed placement and coverage and no other soil tillage is done. However, in traditional sugarcane fields in Brazil, the planting furrow disturbs about $30 \%$ of the soil surface $(0-30 \mathrm{~cm})$ and makes it difficult to adopt no-till in its totality. Therefore, until now, notill in sugarcane fields is a type of reduced tillage where around $30 \%$ of surface layer is disturbed by the planting furrow made once every 5- or 6-year period. In the future, the adoption of new technologies of planting, such as transplanting sugarcane seedlings already used in some areas, can change this scenario. This improved technology will reduce soil disturbance, improve the potential for soil $\mathrm{C}$ accumulation, and contribute to mitigating GHG emissions in sugarcane crop production.

Severe soil compaction is another constraint to adopting no-till in sugarcane. In traditional green cane areas in Brazil, soils are compacted during the replanting period, and in most cases, tillage operations are performed. The intense machinery traffic and the attendant trampling aggravate soil compaction (Braunack and McGarry 1998; De Souza et al. 2012). It is assumed that adoption of reduced tillage in sugarcane fields should involve strategies of controlled and reduced traffic to minimize the stump trampling and soil compaction in the seedling zone (Braunack and McGarry 2006). These strategies are needed to increase the rate of water infiltration and soil biological activity (Tullberg et al. 2007), and enhance soil C sequestration. However, studies evaluating the adoption of reduced tillage in sugarcane fields under controlled traffic conditions in Brazil are scanty and a researchable priority.

\subsection{Inorganic synthetic $\mathbf{N}$ fertilizer}

The consumption of synthetic nitrogen $(\mathrm{N})$ fertilizers in Brazil has increased $\sim 30$ times during 1960 to 2002 (Filoso et al. 2006), and there is a great concern regarding the rational management of N fertilizer. Sugarcane cultivation in Brazil is highly efficient because of favorable growing conditions and produces high yields even with low $\mathrm{N}$ fertilizer inputs compared with that from other biofuel feedstocks such as corn (Heffer and Prud'homme 2008). Recommended rates of N application in Brazil (60-100 $\mathrm{kg} \mathrm{N}$ ha $^{-1}$ year $^{-1}$ ) are significantly lower than those in Australia (160-200 kg $\mathrm{N} \mathrm{ha}^{-1}$ year $^{-1}$ ), India (150-400 $\mathrm{kg} \mathrm{N} \mathrm{ha}^{-1}$ year $\left.^{-1}\right)$, and China (100-755 kg N ha ${ }^{-1}$ year $^{-1}$ ) (Robinson et al. 2011), which is an important factor leading to a high energy balance in sugarcane ethanol production (Manochio et al. 2017).

Further, biological $\mathrm{N}$ fixation can also supply a part of $\mathrm{N}$ demand for sugarcane cultivation in Brazil (Boddey et al. 1995; Medeiros et al. 2006; James and Baldani 2012; Urquiaga et al. 2012). An annual $\mathrm{N}$ input through biological fixation in sugarcane has been estimated at $58 \mathrm{~kg} \mathrm{ha}^{-1}$ year $^{-1}$ by Resende et al. (2006) compared with that of $40 \mathrm{~kg}$ $\mathrm{N} \mathrm{ha}^{-1}$ year $^{-1}$ by Urquiaga et al. (2012). However, studies conducted in Brazil (Cantarella et al. 2014), Australia (Biggs et al. 2002), and South Africa (Hoefsloot et al. 2005) did not show any positive impact of inoculation and concluded that $\mathrm{N}$ inputs via biological fixation may be insignificant in sugarcane fields. The contribution of biological $\mathrm{N}$ fixation on sugarcane- $\mathrm{N}$ budget is, therefore, a debatable issue and a researchable priority.

Thus, chemical $\mathrm{N}$ fertilization is needed to maximize sugarcane yields. Input of synthetic $\mathrm{N}$ into agricultural systems contributes to increased $\mathrm{N}$ losses via atmospheric, surface, and/or leaching pathways (Lal et al. 2011). While synthesizing the data regarding in situ measurements of losses of $\mathrm{N}$ by leaching, denitrification, uptake, immobilization, and volatilization under Brazilian field conditions, Otto et al. (2016) concluded that $26 \%$ of $\mathrm{N}$ fertilizer applied in sugarcane fields is absorbed by crop, $32 \%$ is immobilized in the soil, and the remaining $42 \%$ is lost by $\mathrm{NH}_{3}$ volatilization (19\%), leaching (5.6\%), $\mathrm{N}_{2} \mathrm{O}$ emissions (1.8\%), and other pathways $(16 \%)$. Otto and colleagues reported that only $28 \%$ of the aboveground sugarcane $\mathrm{N}$ content comes from $\mathrm{N}$ fertilizers and $72 \%$ is derived from other sources, such as mineralization of soil organic matter, biological $\mathrm{N}$ fixation, and dry and wet deposition. Several studies in Brazil with ${ }^{15} \mathrm{~N}$-labeled nitrogen have shown that mineralization of soil organic matter is the main source of $\mathrm{N}$ for sugarcane rather than $\mathrm{N}$ fertilizers (Dourado-Neto et al. 2010; Franco et al. 2011; Otto et al. 2013; Vieira-Megda et al. 2015), indicating that N supply from mineralization is an important aspect to be considered in $\mathrm{N}$ management systems, especially where increasing the $\mathrm{N}$ use efficiency is a primary goal.

$\mathrm{NH}_{3}$ volatilization is one of the main sources of $\mathrm{N}$ losses in sugarcane fields, and such losses are mostly associated with application of urea on the soil surface without incorporation into the soil (Otto et al. 2016). The application of urea on top of the sugarcane straw layer may lead to losses by $\mathrm{NH}_{3}$ volatilization ranging from 24 to $37 \%$ of applied $\mathrm{N}$ fertilizer (Mariano et al. 2012; Soares et al. 2012). However, using other types of $\mathrm{N}$ fertilizers in sugarcane fields (i.e., ammonium nitrate and ammonium sulfate) could be an important strategy to attenuate these losses (Costa et al. 2003). Further, the 
incorporation of $\mathrm{N}$ urea into the soil and the use of urease inhibitors (Cantarella et al. 2008) can significantly reduce $\mathrm{NH}_{3}$ volatilization and increase biomass production (Castro et al. 2014; Gava et al. 2001; Soares et al. 2012).

The recent adoption of green cane harvest has enhanced $\mathrm{N}$ losses by volatilization in sugarcane fields (Costa et al. 2003; Mariano et al. 2012). Sugarcane straw has a high C/N ratio and its deposition on the soil surface leads to $\mathrm{N}$ immobilization by microorganisms (Vitti et al. 2007), and thereby higher $\mathrm{N}$ rates have been recommended to enhance availability to the sugarcane crop. In a long-term perspective, however, the adoption of green harvest system may also attenuate losses by volatilization from synthetic $\mathrm{N}$ fertilization. Basanta et al. (2003) indicated that unburned straw remaining on soil surface would result in an average $\mathrm{N}$ recycling of $105 \mathrm{~kg} \mathrm{ha}^{-1}$ year $^{-1}$, which may lead to a more efficient recycling of fertilizer $\mathrm{N}$ applied to the system. The available information indicates that the fertilizer $\mathrm{N}$ application should not be reduced during the first 6 years after adoption of residue mulching in sugarcane management, and small reductions may only be possible over a longer term (>15 years; Robertson and Thorburn 2007).

Several studies in sugarcane fields in Brazil have also shown that losses through $\mathrm{NO}_{3}^{-}$leaching may range from 0 to $22.5 \%$ (Oliveira et al. 2002; Ghiberto et al. 2009; Ghiberto et al. 2011; Ghiberto et al. 2015), indicating that a large proportion of the $\mathrm{N}$ applied in sugarcane production is lost to the atmosphere. Leaching of $\mathrm{NO}_{3}{ }^{-}$can aggravate several environmental problems, especially concerning water quality and the groundwater pollution. The reported rates of $\mathrm{NO}_{3}{ }^{-}$leached in sugarcane fields in Brazil are smaller than those observed in Australia, which reflect the lower $\mathrm{N}$ application rate and best soil conditions (Otto et al. 2016). In Brazil, sugarcane is cultivated mainly in deep, well-drained, and highly weathered soils, which cause relatively small amounts of $\mathrm{NO}_{3}{ }^{-}$entering into the groundwater. However, $\mathrm{NO}_{3}{ }^{-}$losses can be higher when sugarcane is cultivated in sandy and/or shallow soils, and additional research is needed to validate this hypothesis.

Nitrous oxide $\left(\mathrm{N}_{2} \mathrm{O}\right)$ is another potent $\mathrm{GHG}$ emitted mainly from agricultural activities such as application of $\mathrm{N}$ fertilizer. Field experiments show that $\mathrm{N}_{2} \mathrm{O}$ emissions in sugarcane fields may range from 0.21 to $3.03 \%$ depending on soil type and the amount of $\mathrm{N}$ fertilizer and sugarcane residues maintained in sugarcane fields (Carmo et al. 2013; Pitombo et al. 2016; Siqueira Neto et al. 2016). Because of the scarcity of field data, Life Cycle Assessment inventories are based on emission factor of $1 \%$ of the $\mathrm{N}$ fertilizer applied (IPCC 2006), and therefore $\mathrm{N}_{2} \mathrm{O}$ emissions from $\mathrm{N}$ fertilization may represent $30-40 \%$ of the total GHG emissions associated with sugarcane production (Bordonal et al. 2013; Lisboa et al. 2011).

Adoption of best management practices (e.g., switching the sources of N, split application to coincide with crop demand, precision farming to reduce rates of $\mathrm{N}$ application in over- fertilized regions, slow-release fertilizers, and nitrification inhibitors) has a potential to mitigate $\mathrm{N}_{2} \mathrm{O}$ emissions and enhance $\mathrm{N}$ use efficiency by up to $50 \%$ (Reay et al. 2012). For instance, application of urease inhibitors can reduce the $\mathrm{N}$ volatilization by 15 to $78 \%$ during the sugarcane-growing season (Cantarella et al. 2008; Soares et al. 2015). Also, $\mathrm{N}_{2} \mathrm{O}$-induced emissions by $\mathrm{N}$ fertilizers depend on the $\mathrm{N}$ sources (e.g., ammonium nitrate and urea) and the application rate (Signor et al. 2013; Allen et al. 2010). The application of ammonium sulfate and the incorporation of urea into the soil can decrease $\mathrm{N}$ losses through volatilization and water runoff from sugarcane fields (Prasertsak et al. 2002).

Enhanced efficiency of fertilization, optimization of byproduct usage (e.g., vinasse and filtercake), and increased use of green manure through crop rotation are important strategies to reduce $\mathrm{N}$ fertilizer inputs and associated $\mathrm{N}_{2} \mathrm{O}$ emissions (Otto et al. 2016). Further, including legumes in crop rotations makes considerable net input of $\mathrm{N}$ to soil (Peoples et al. 1995). However, little is known about how much sugarcane could assimilate $\mathrm{N}$ from biological fixation by using legumes as N-fixing crop. Hemwong et al. (2009) observed that legume residues can substitute only the basal fertilization of $\mathrm{N}$, but sugarcane requires additional $\mathrm{N}$ supplement at later stages. Park et al. (2010) estimated potential reduction in fertilizer application rate through biological $\mathrm{N}$ fixation at $100 \%$ in the first ratoon, and 60,25 , and $10 \%$ in the subsequent ratoons.

Further research is needed to elucidate and validate the benefits of $\mathrm{N}$-fixing crops as a source of $\mathrm{N}$ in sugarcanelegume rotation cropping systems. Furthermore, $\mathrm{N}$ input in the soil by biological fixation is part of a natural process, whereas the use of chemical $\mathrm{N}$ fertilizer requires energy (Crews and Peoples 2004). Research is also needed to establish the link between biological $\mathrm{N}$ fixation and $\mathrm{N}_{2} \mathrm{O}$ emissions from $\mathrm{N}$-fixing crops (Jensen et al. 2012). Some researchers argue that biological $\mathrm{N}$ fixation may not be a direct source of $\mathrm{N}_{2} \mathrm{O}$ (Barton et al. 2011; Rochette and Janzen 2005). Similarly, inoculation with plant growth promoting microorganisms is a promising management option to increase the efficiency of fertilizers use, promote plant nutrient use efficiency (Adesemoye and Kloepper 2009), and protect plants against pathogens. Based on these beneficial aspects, plant growth-promoting microorganisms are potential alternatives or have synergistic effects with traditional fertilizers for enhancing plant productivity and improving soil quality without environmental pollution (Bhardwaj et al. 2014).

\subsection{Vinasse fertirrigation}

Vinasse is the main residue of the sugarcane biofuel industry and is produced on average of $13 \mathrm{~L}$ for each liter of ethanol (Kumar et al. 1998). Vinasse is a dark-brown high-strength wastewater with dissolved organic $\mathrm{C}$ content of $50-150 \mathrm{~g} \mathrm{~L}^{-1}$, 
which may be 100 times more than that in the domestic sewage (Fuess and Garcia 2014). The ethanol industry in Brazil regulated the disposal of vinasse during the mid-1980s to be recycled back into the fields (Filoso et al. 2015), because of well-documented problems of anoxia in water bodies due to the high loads of vinasse (Christofoletti et al. 2013). Thus, the primary use of vinasse at present is an application in sugarcane fields as fertirrigation.

The application of vinasse in sugarcane fields is the least expensive and the simplest solution with several agronomic benefits (Oliveira et al. 2015), including increase in sugarcane yields (Resende et al. 2006), improvement in soil quality (Christofoletti et al. 2013), increase in soil inputs of C and N (Parnaudeau et al. 2008), reduction of fresh water used in full and salvage irrigation, and decrease in synthetic fertilizers use (Smeets et al. 2008; Macedo et al. 2008). Vinasse fertirrigation improves sugarcane yields in both short and long term primarily because of its high potassium content (Resende et al. 2006). However, the repeated application of vinasse may lead to potassium accumulation and leaching into the groundwater (Da Silva et al. 2014b), which can potentially affect aquatic ecosystems (De Moraes et al. 2010). The adverse effects of vinasse fertirrigation also include soil salinization, soil over fertilization, soil and groundwater acidification, contamination by specific ions, among others (Fuess and Garcia 2014).

Vinasse is also an important source of GHG emission: during storage and transportation (Oliveira et al. 2015; Oliveira et al. 2017b) and after the application in sugarcane fields (Carmo et al. 2013; Oliveira et al. 2013; Paredes et al. 2014; Siqueira Neto et al. 2016; Pitombo et al. 2016; Silva et al. 2017). Assessing the emissions from vinasse during storage and transportation by open channels, Oliveira et al. (2015) concluded that this phase is an important source of $\mathrm{CH}_{4}$ (ranging from 394 to $1092 \mathrm{mg} \mathrm{m}^{-2} \mathrm{~h}^{-1}$ ) and should be included in future GHG inventories for sugarcane ethanol production. Further, comparing the two most widespread systems of vinasse storage and transportation-open channels and tanks-Oliveira et al. (2017b) observed higher emissions from vinasse stored and transported by channels $(1.36 \mathrm{~kg}$ $\mathrm{CO}_{2}$ eq $\mathrm{m}^{-3}$ of transported vinasse), whereas 85 to $90 \%$ of these rates were measured from the uncoated section of channel. Oliveira and colleagues concluded that improvements in the vinasse distribution systems through adoption of new technologies, such as the adoption of closed pipes instead of open channels, could reduce GHG emissions and make a significant contribution towards a cleaner production of sugarcane ethanol.

Application of vinasse in the field does not influence $\mathrm{CH}_{4}$ emissions but reduces soil aeration and increases the availability of dissolved organic $\mathrm{C}$ to microorganisms, in which the higher microbial activity in anaerobic sites leads to high $\mathrm{N}_{2} \mathrm{O}$ losses (Siqueira Neto et al. 2016). Estimating $\mathrm{N}_{2} \mathrm{O}$ emissions from soils treated with vinasse and mineral $\mathrm{N}$ fertilizer at different stages of sugarcane growth, Carmo et al. (2013) observed higher $\mathrm{N}_{2} \mathrm{O}$ emissions in treatments receiving vinasse than those receiving only the mineral fertilizer. Similar trends have been reported in other studies (Paredes et al. 2014; Siqueira Neto et al. 2016; Pitombo et al. 2016; Silva et al. 2017). Application of vinasse associated with sugarcane straw on the soil surface can also increase $\mathrm{N}_{2} \mathrm{O}$ emissions (Carmo et al. 2013; Pitombo et al. 2016; Oliveira et al. 2013).

$\mathrm{N}_{2} \mathrm{O}$ emissions from vinasse fertirrigation also depend on the method of its application. An application of concentrated vinasse reduces $\mathrm{N}_{2} \mathrm{O}$ emissions compared with that of fresh vinasse and can be considered a key strategy to mitigate GHG emission in the Brazilian sugarcane bioethanol sector (Pitombo et al. 2016). Similarly, evaluating the trade-offs between $\mathrm{N}_{2} \mathrm{O}$ emissions, crop productivity, and irrigation in sugarcane plantation, Silva et al. (2017) concluded that applications of synthetic $\mathrm{N}$ fertilizer and vinasse separated in time by at least a month can avoid the synergistic effects of joint application on $\mathrm{N}_{2} \mathrm{O}$ emissions and might be considered a mitigation strategy.

Another possible GHG mitigation strategy is the anaerobic digestion and concentration of vinasse. Assessing GHG emissions from fresh and biodigested vinasse from sugar beet ethanol production in different time of storage and after application in the soil, Moraes et al. (2017) observed that anaerobic digestion was effective in mitigating GHG emissions during storage, in which no $\mathrm{CH}_{4}$ emissions were observed in digested vinasse against $333 \mathrm{~g} \mathrm{CH}_{4} \mathrm{~L}^{-1}$ of fresh vinasse and after field application. The digestate also showed lower $\mathrm{N}_{2} \mathrm{O}$ emissions by $48-78 \%$ than those from fresh vinasse, depending on the retention time prior to soil application.

The concentration of vinasse is an economic alternative to reduce transportation and logistical costs, which reduces the large amount of water that makes up its composition (Otto et al. 2017) and contributes to mitigating GHG emissions. While this practice introduces high efficiency and quality in the field application, it is not well known whether the concentrated vinasse can reduce the GHG emissions in comparison with the application of the fresh vinasse. However, it is likely to reduce the $\mathrm{N}$ losses once this practice may increase the nutrient efficiency by the crop. The impacts of vinasse loadings on soil biogeochemical processes are not fully understood (Filoso et al. 2015).

\subsection{Water use and quality}

Numerous crops are used globally to produce bioenergy, but not all of them meet the requirements of a high yield and environmentally sustainable feedstock. Approximately $70 \%$ of the global water withdrawals are attributed to agricultural activities (Aquastat 2012), and the increased demands for food in combination with a shift from fossil energy towards bioenergy are putting additional pressure on freshwater 
resources (Gerbens-Leenes et al. 2009). Concerns regarding the environmental impacts of biofuel production have increased considerably since the 2000 s, including those related to water quantity and quality (Filoso et al. 2015).

Sugarcane is one of the most favorable options to produce ethanol in terms of water footprint (WF; Table 1), which represents the amount of water consumed per unit ethanol produced (Gerbens-Leenes et al. 2009). Over the three decades (1985-2015), sugarcane mills have been relatively inefficient water users because of the adoption of water open-circuit technology, which accounts for a water withdrawal of 15$20 \mathrm{~m}^{3} \mathrm{Mg}^{-1}$ of cane. Currently, there has been a substantial reduction in consumption to $\sim 1.85 \mathrm{~m}^{3} \mathrm{Mg}^{-1}$ of cane, especially by implementing better technologies to improve water use efficiency (Yeh et al. 2011; Filoso et al. 2015). Reducing or recycling water from the sugarcane washing has also an important impact on the overall improvement during the industrial stage, since the burnt sugarcane is dirtier than the green and requires larger volume of water for washing (Silva et al. 2014). For instance, in the São Paulo state, which has the largest concentration of ethanol and sugar mills in Brazil, authorities established a target to limit water use in sugarcane industry by $1.0 \mathrm{~m}^{3} \mathrm{Mg}^{-1}$ of cane and $0.7 \mathrm{~m}^{3} \mathrm{Mg}^{-1}$ of cane in areas under water scarcity (Agro-Environmental Zoning for Sugar Alcohol Sector for the São Paulo State). One means of achieving such commitment is through optimization of water reuse in sugarcane industry, which could decrease consumption by $0.8 \mathrm{~m}^{3} \mathrm{Mg}^{-1}$ of cane and lead to a total usage of around $0.6 \mathrm{~m}^{3} \mathrm{Mg}^{-1}$ of cane (Chavez-Rodriguez et al. 2013).

Despite the developments so far achieved in the industrial phase of ethanol production, assessment of water consumption is also pertinent during the sugarcane agricultural production. In Brazil, bioethanol is produced from sugarcane under dryland conditions, but the use of irrigation can boost sugarcane yields particularly in regions with limited water availability (Scarpare et al. 2016a). Nevertheless, the necessity for irrigation to meet large-scale ethanol demand may further strain limited water resources (Popp et al. 2014). The average WF of the sugarcane production in south-central Brazil is $137 \mathrm{~m}^{3} \mathrm{Mg}^{-1}$ of cane, ranging from $124 \mathrm{~m}^{3} \mathrm{Mg}^{-1}$ in São Paulo state to $170 \mathrm{~m}^{3} \mathrm{Mg}^{-1}$ in Paraná (Hernandes et al. 2014). Variations in WF may be due to the crop evapotranspiration in relation to climate and the yield potential, which vary with soil and management.

Agronomically, there are several options to reduce the sugarcane WF. Full and supplemental irrigation reduce water deficit in critical period of the crop development and are important strategies to increase biomass yield with a little additional water use (Rockström et al. 2010; Cardozo et al. 2016). The adoption of salvage and full irrigation regimes in south-central Brazil reduced sugarcane WF by about 1 and $7 \%$ compared to that under rainfed condition, respectively (Hernandes et al. 2014). Irrigation may also reduce the $\mathrm{C}$ footprint of sugarcane production by $59 \%$ against dryland areas and promote the intensification of land use (Cardozo et al. 2016).

However, the production of sugarcane in Brazil is currently managed by applying merely vinasse or wastewater as a salvage irrigation. The salvage irrigation is applied under low volumes (e.g., ranging from 100 to $200 \mathrm{~m}^{3} \mathrm{ha}^{-1}$ year $^{-1}$ ) and largely uses nutrient-rich wastewater generated from industrial production (e.g., sugar and bioethanol) instead of freshwater (Yeh et al. 2011). The use of vinasse as salvage irrigation supplies nutrients and increases soil moisture during periods of water stress, resulting in better sugarcane sprouting and higher yields (Scarpare et al. 2016b). The adoption of irrigation in bioenergy production systems can change the fieldlevel water availability, evapotranspiration rates, and downstream water flows (Berndes et al. 2015). However, the direction and magnitude of such changes depend on the location and the specific management (Sterling et al. 2013).

There exists a vast potential in agricultural sector to improve water availability and quality by increasing soil water storage and reducing losses. Semi-perennial bioenergy crops (i.e., sugarcane) have an extensive root system, reduced need for tillage operations during the crop cycle, and long-term soil cover and better soil protection, which tend to have lower water quality impacts than conventional crops (Dimitriou et al. 2011). Using a Life Cycle Assessment approach, recent studies estimated that the adoption of no-till in sugarcane fields improves the quality of freshwater and reduces the contamination of water bodies (Da Silva et al. 2014a; Chagas et al. 2016). Adoption of conservationist management practices (e.g., reduced tillage, soil cover by crop residues after green harvest and cover crops) also attenuates the erosioninduced losses (e.g., water, sediment, and nutrients) in sugarcane fields (Martins Filho et al. 2009; Da Silva et al. 2012), and consequently reduces WF of ethanol production. Scarpare et al. (2016b) estimated sugarcane WF and observed average green, blue, and gray WFs of 145,38 , and $18 \mathrm{~m}^{3} \mathrm{Mg}^{-1}$, respectively. The larger fraction of green against blue WF confirms the importance of rainfall, which endorses why Brazilian sugarcane growers limit their production to reasonable rainfall regions.

Even with the smaller gray component of WF, Scarpare et al. (2016b) highlighted the lack of good indicators of the impacts of fertilizers, herbicides, insecticides, and fungicides on water bodies, suggesting that comprehensive assessments by gray WF should be performed to identify the most hazardous substances in the sugarcane production chain. Corroborating these findings, Guarengui and Walter (2016) concluded that it was not possible to rigorously determine the contribution of large-scale production of sugarcane for changing water flows and reducing water quality, despite the use of the best publicly available database in the São Paulo state, Brazil. 
Similar to the cultivation of other commercial crops in Brazil (e.g., soybean and corn), cultivation of sugarcane also requires the application of pesticides. An effective disease, pest, and weed control is crucial because a reduction of more than $80 \%$ can occur in sugarcane production (Smeets et al. 2008). Pesticides are typically used, but in limited quantities per hectare compared to those in conventional crops (e.g., $40 \%$ less compared with corn and more than $90 \%$ less than in other crops such as coffee, citric, or soybean) (Macedo 2005). Agrochemicals usually applied in sugarcane areas include herbicides, insecticides, maturators, adhesive spreading agents, biological and microbial products, vegetable extracts, and pheromones that are used to control pests and undesirable weeds, with biological products having no toxicological characteristics and risks.

Despite the fact that sugarcane plantation consumes less pesticides in comparison with other crops, some researchers argue that the use of pesticides in sugarcane areas has increased substantially in Brazil in recent years (Velasco et al. 2012; Warren et al. 2003). The advent of green mechanized harvest with the absence of fire has caused significant changes in sugarcane agrosystems due to modification in soil cover conditions related to annual deposition of large amount of straw on the soil surface (Carvalho et al. 2007a). The residue retention can aggravate infestation by weeds and the populations of pests and their natural enemies (Dinardo-Miranda and Fracasso 2013). Assessing the contamination by herbicides in Ipojuca River in northeast Brazil, Ferreira et al. (2016) observed residual detection of diuron and ametryn at all collection points. The presence of these molecules in water bodies, even at low concentrations, may originate perceptible alterations on long-term basis. Jacomini et al. (2011) also observed high levels of ametryn in three rivers from areas under sugarcane cultivation in southern Brazil. These findings provide new insights into the impact of sugarcane bioethanol on the pollution of freshwater at a watershed level.

Regardless of the impacts of increased use of pesticides, some adaptations in agricultural management are needed to minimize future risks to quality of natural waters. Among several opportunities to decrease the use of pesticides include the application of biological control, in which Brazil's major programs in this field are already incorporated within the sugarcane cropping systems. Integrated pest management with introduction of biological control and crop rotation could also reduce the use of agrochemicals in the future, besides the development of resistant cane varieties especially in relation to disease control (Smeets et al. 2008). Without adequate environmental and regulatory policies, therefore, future expansion of sugarcane in Brazil could pose a threat to water quality and put drinking water supplies at risk (Hess et al. 2016).

\section{Conclusions}

Barriers to large-scale deployment of biofuels include concerns regarding the sustainability of agricultural practices, high consumption of agricultural inputs, greenhouse gas emissions, land use change, food production, water use and quality, among others. Appropriate agricultural practices are those that reduce the impact of greenhouse gas emissions while enhancing the adaptive capacity of agricultural systems to climate change, increasing crop yields, and advancing food security. Sugarcane ethanol can play an important role in greenhouse gas mitigation providing that sustainability of agricultural practices and the efficiency of ethanol production are enhanced and sustained.

Adoption of innovative technologies indicates that improvements in both agricultural and industrial sectors have led to a better sustainability and acceptance of sugarcanederived products (e.g., ethanol, sugar, and bioelectricity) in the global market. Great advances made in the sugarcane crop production from 1975 to 2015 in Brazil (e.g., the improvement of energy balance, greenhouse gas savings, water recycling, lower water footprint, and higher yields with low fertilizer inputs than other biofuel feedstocks) make the sugarcane-based ethanol as one of the most successful global bioethanol programs. Continuous developments in sustainability of agricultural practices during the decade ending in 2015 have also contributed to these outcomes. Notable among these are as follows: reducing area under residue burning in the sugarcane preharvest, decreasing the input of synthetic fertilizers by recycling the industrial byproducts (e.g., vinasse), achieving a rational and sustainable pathway for sugarcane expansion through Agro-ecological Zoning program, and avoiding the sugarcane transition over biomes such as Amazon and Pantanal.

However, there is a large potential of improving the efficiency of agricultural management in sugarcane cropping systems, such as closing the yield gaps and decreasing inputs of synthetic fertilizers. Along with these improvements, the intensification and restoration of degraded pastures for livestock sector are key opportunities that must be encouraged to provide additional food and ensure the benefits of sugarcane as a sustainable feedstock for bioenergy production. There also exists a strong need for a more integrated perspective on the management of agricultural systems, so that synergies among sugarcane with food and feed crops are important developments that deserve special attention. To meet the increasing world demand for bioethanol in a sustainable manner beyond the avoided emissions provided by substitution of fossil fuels, further advances may be achieved through the potential to recovering sugarcane straw for bioenergy production (e.g., bioelectricity and second-generation ethanol), as well as implementing best management practices in the sugarcane production chain (e.g., total eradication of preharvest burning, 
accurate straw recovery rate, enhancing $\mathrm{N}$ use efficiency, anaerobic digestion and concentration of vinasse, increased use of green manure as crop rotation, application of slow-release fertilizers and nitrification inhibitors, and adoption of reduced tillage involving strategies of controlled traffic in sugarcane fields) across all regions in Brazil. These are among researchable priorities for consolidating the large potential of sugarcane for increasing soil $\mathrm{C}$ stocks, offsetting the anthropogenic $\mathrm{CO}_{2}$, and effectively mitigating the global climate change.

Acknowledgements The authors would like to thank the Sugarcane Renewable Electricity project - SUCRE/PNUD (grant number BRA/10/ G31) and the National Council for Scientific and Technological Development-CNPq (contract grant numbers 142232/2012-2 and 150160/ 2016-0), Brazil, for the grants awarded for the development of this study. We would like to sincerely thank Mauricio R. Cherubin and Bernardo M. M. N. Borges for designing the figures 3 and 7 respectively.

\section{References}

Adami M, Theodor Rudorff BF, Freitas RM, Aguiar DA, Sugawara LM (2012) Remote sensing time series to evaluate direct land use change of recent expanded sugarcane crop in Brazil. Sustainability 4:574 585. https://doi.org/10.3390/su4040574

Adesemoye AO, Kloepper JW (2009) Plant-microbes interactions in enhanced fertilizer-use efficiency. Appl Microbiol Biotechnol 85:112. https://doi.org/10.1007/s00253-009-2196-0

Aguiar DA, Theodor Rudorff BF, Silva WF, Adami M, Mello MP (2011) Remote sensing images in support of environmental protocol: monitoring the sugarcane harvest in São Paulo state, Brazil. Remote Sens 3:2682-2703. https://doi.org/10.3390/rs3122682

Allen DE, Kingston G, Rennenberg H, Dalal RC, Schmidt S (2010) Effect of nitrogen fertilizer management and waterlogging on nitrous oxide emission from subtropical sugarcane soils. Agric Ecosyst Environ 136:209 217. https://doi.org/10.1016/j.agee.2009.11.002

Antle J, Ogle S (2012) Influence of soil C, $\mathrm{N}_{2} \mathrm{O}$ and fuel use on GHG mitigation with no-till adoption. Clim Chang 111:609-625. https:// doi.org/10.1007/s10584-011-0193-7

Aquastat (2012) Water uses. UN Food and Agriculture Association Water Statistics. Food and Agriculture Organization of the United Nations (FAO). http://www.fao.org/nr/water/aquastat/water use/index.stm. Accessed 25 Nov 2015

Aquino GS, de Conti MC, da Costa DC, Shahab M, Santiago AD (2017) Sugarcane straw management and its impact on production and development of ratoons. Ind Crop Prod 102:58-64. https://doi.org/ 10.1016/j.indcrop.2017.03.018

Arbex MA, Martins LC, de Oliveira RC, Amador Pereira LA, Arbex FF (2007) Air pollution from biomass burning and asthma hospital admissions in a sugar cane plantation area in Brazil. J Epidemiol Community Health 61:395-400. https://doi.org/10.1136/jech.2005.044743

Balat M, Balat H (2009) Recent trends in global production and utilization of bio-ethanol fuel. Appl Energy 86:2273-2282. https://doi.org/ 10.1016/j.apenergy.2009.03.015

Barretto AGOP, Berndes G, Sparovek G, Wirsenius S (2013) Agricultural intensification in Brazil and its effects on land-use patterns: an analysis of the 1975-2006 period. Glob Change Biol 19:1804-1815. https://doi.org/10.1111/gcb.12174

Barton L, Butterbach-Bahl K, Kiese R, Murphy DV (2011) Nitrous oxide fluxes from a grain-legume crop (narrow-leafed lupin) grown in a semiarid climate. Glob Change Biol 17:1153-1166. https://doi.org/ 10.1111/j.1365-2486.2010.02260.x
Basanta MV, Dourado-Neto D, Reichardt K, Bacchi OOS, Oliveira JCM (2003) Management effects on nitrogen recovery in a sugarcane crop grown in Brazil. Geoderma 116:235-248. https://doi.org/10. 1016/S0016-7061(03)00103-4

Beeharry RP (2001) Carbon balance of sugarcane bioenergy systems. Biomass Bioenergy 20:361-370. https://doi.org/10.1016/S09619534(00)00094-5

Berndes G, Youngs H, Ballester MVR, Cantarella H, Cowie AL, Jewitt G, Martinelli LA, Neary D (2015) Soils and water. In: Souza GM, Victoria RL, Joly CA, Verdade LM (eds) Bioenergy \& sustainability: bridging the gaps. FAPESP, São Paulo, pp 618-659

Bessou C, Ferchaud F, Gabrielle B, Mary B (2011) Biofuels, greenhouse gases and climate change. A review. Agron Sustain Dev 31:1-79. https://doi.org/10.1051/agro/2009039

Bhardwaj D, Ansari MW, Sahoo RK, Tuteja N (2014) Biofertilizers function as key player in sustainable agriculture by improving soil fertility, plant tolerance and crop productivity. Microb Cell Factories 13:66. https://doi.org/10.1186/1475-2859-13-66

Biggs IM, Stewart GR, Wilson JR, Critchley C $(2002){ }^{15} \mathrm{~N}$ natural abundance studies in Australian commercial sugarcane. Plant Soil 238: 21-30. https://doi.org/10.1023/A:1014280420779

Boddey RM, Soares LHB, Alves BJR, Urquiaga S (2008) Bio-ethanol production in Brazil. In: Pimentel D (ed) Biofuels. Solar and Wind as Renewable Energy Systems. Springer, Netherlands, pp 321-356. https://doi.org/10.1007/978-1-4020-8654-0_13

Boddey RM, de Oliveira OC, Urquiaga S, Reis VM, de Olivares FL, Baldani VLD, Döbereiner J (1995) Biological nitrogen fixation associated with sugar cane and rice: contributions and prospects for improvement. Plant Soil 174:195-209. https://doi.org/10.1007/ BF00032247

Bolonhezi D, Branco RBF, Perdoná MJ, Carbonell SAM, Chiorato AF (2010) Intercropping of sugarcane with common bean in no-tillage and different nitrogen rates. In: 19th World Congress of Soil Science, Soil Solutions for a Changing World, Brisbane, Australia, pp 23-26

Bordonal RO, De Figueiredo EB, Aguiar DA, Adami M, Theodor Rudorff BF, La Scala N (2013) Greenhouse gas mitigation potential from green harvested sugarcane scenarios in São Paulo State, Brazil. Biomass Bioenergy 59:195-207. https://doi.org/10.1016/j. biombioe.2013.08.040

Bordonal RO, De Figueiredo EB, La Scala N (2012) Greenhouse gas balance due to the conversion of sugarcane areas from burned to green harvest, considering other conservationist management practices. Glob Change Biol Bioenergy 4:846-858. https://doi.org/10. 1111/j.1757-1707.2012.01193.x

Bordonal RO, Lal R, Alves Aguiar D, De Figueiredo EB, Ito Perillo L, Adami M, Theodor Rudorff BF, La Scala N (2015) Greenhouse gas balance from cultivation and direct land use change of recently established sugarcane (Saccharum officinarum) plantation in south-central Brazil. Renew Sust Energ Rev 52:547-556. https:// doi.org/10.1016/j.rser.2015.07.137

Bordonal RO, Lal R, Ronquim CC, De Figueiredo EB, Carvalho JLN, Maldonado W Jr, Milori DMBP, La Scala JN (2017) Changes in quantity and quality of soil carbon due to the land-use conversion to sugarcane (Saccharum officinarum) plantation in southern Brazil. Agric Ecosyst Environ 240:54-65. https://doi.org/10.1016/j.agee. 2017.02.016

Börjesson P (2009) Good or bad bioethanol from a greenhouse gas perspective - what determines this? Appl Energy 86:589-594. https:// doi.org/10.1016/j.apenergy.2008.11.025

Braunack M, McGarry D (1998) Is all that tillage necessary. Austr Sugarcane 1:12-14

Braunack MV, McGarry D (2006) Traffic control and tillage strategies for harvesting and planting of sugarcane (Saccharum officinarum) in Australia. Soil Till Res 89:86-102. https://doi.org/10.1016/j.still. 2005.07.002 
Campos LHF, Carvalho SJP, Christoffoleti PJ, Fortes C, Silva JS (2010) Sistemas de manejo da palhada influenciam acúmulo de biomassa e produtividade da canade-açúcar (var. RB855453). Acta Sci Agron 32:345-350. https://doi.org/10.4025/actasciagron.v32i2.3703

Cançado JED, Saldiva PHN, Pereira LAA, Lara L, Artaxo P (2006) The impact of sugar cane-burning emissions on the respiratory system of children and the elderly. Environ Health Persp 114:725-729. https:// doi.org/10.1289/ehp.8485

Cantarella H, Ocheuze Trivelin PC, Michelucci Contin TL, Ferreira Dias FL, Rossetto R (2008) Ammonia volatilisation from urease inhibitortreated urea applied to sugarcane trash blankets. Sci Agric 65:397401. https://doi.org/10.1590/S0103-90162008000400011

Cantarella H, Montezano ZF, Joris HAW, Vitti AC, Rossetto R, Gava GJC, Dias FLF, Urquiaga S, Reis VM (2014) Nitrogen fertilization and inoculation of sugarcane with diazotrophic bacteria: 13-site-year of field results. Proceedings of the 2nd Brazilian Bio Energy Science and Technology Conference, Campos do Jordão

Capaz RS, Carvalho VSB, Nogueira LAH (2013) Impact of mechanization and previous burning reduction on GHG emissions of sugarcane harvesting operations in Brazil. Appl Energy 102:220-228. https://doi.org/10.1016/j.apenergy.2012.09.049

Cardozo NP, Bordonal RO, La Scala JN (2016) Greenhouse gas emission estimate in sugarcane irrigation in Brazil: is it possible to reduce it, and still increase crop yield? J Clean Prod 112:3988-3997. https:// doi.org/10.1016/j.jclepro.2015.09.040

Carmo JB, Filoso S, Zotelli LC, de Sousa Neto ER, Pitombo LM, DuarteNeto PJ, Vargas VP, Andrade CA, Gava GJC, Rossetto R, Cantarella H, Neto AE, Martinelli LA (2013) Infield greenhouse gas emissions from sugarcane soils in Brazil: effects from synthetic and organic fertilizer application and crop trash accumulation. Glob Change Biol Bioenergy 5:267-280. https://doi.org/10.1111/j.1757-1707.2012. 01199.x

Carvalho JLN, Nogueirol RC, Menandro LMS, Bordonal RO, Borges CD, Cantarella H, Franco HCJ (2017a) Agronomic and environmental implications of sugarcane straw removal: a major review. Glob Change Biol Bioenergy 9:1181-1195. https://doi.org/10. $1111 /$ gcbb. 12410

Carvalho JLN, Hudiburg TW, Franco HCJ, DeLucia EH (2017b) Contribution of above- and belowground bioenergy crop residues to soil carbon. Glob Change Biol Bioenergy 9:1333-1343. https:// doi.org/10.1111/gcbb.12411

Carvalho-Netto O, Bressiani J, Soriano H, Fiori C, Santos J, Barbosa G, Xavier M, Landell M, Pereira G (2014) The potential of the energy cane as the main biomass crop for the cellulosic industry. Chem Biol Technol Agric 1:1-8. https://doi.org/10.1186/s40538-014-0020-2

Castro SGQ, Franco HJC, Mutton MA (2014) Harvest managements and cultural practices in sugarcane. Rev Bras Ci Solo 38:299-306. https://doi.org/10.1590/S0100-06832014000100030

Cerri CC, Galdos MV, Maia SMF, Bernoux M, Feigl BJ, Powlson D, Cerri CEP (2011) Effect of sugarcane harvesting systems on soil carbon stocks in Brazil: an examination of existing data. Eur J Soil Sci 62:23-28. https://doi.org/10.1111/j.1365-2389.2010.01315.x

Chagas MF, Bordonal RO, Cavalett O, Carvalho JLN, Bonomi A, La Scala N (2016) Environmental and economic impacts of different sugarcane production systems in the ethanol biorefinery. Biofuels Bioprod Biorefin 10:89-106. https://doi.org/10.1002/bbb.1623

Chakravorty U, Hubert M-H, Nøstbakken L (2009) Fuel versus food. Annu Rev Resour Econ 1:645-663. https://doi.org/10.1146/ annurev.resource.050708.144200

Chavez-Rodriguez MF, Mosqueira-Salazar KJ, Ensinas AV, Nebra SA (2013) Water reuse and recycling according to stream qualities in sugar-ethanol plants. Energy Sustain Dev 17:546-554. https://doi. org/10.1016/j.esd.2013.08.003

Cherubin MR, Karlen DL, Franco ALC, Cerri CEP, Tormena CA, Cerri CC (2016) A soil management assessment framework (SMAF) evaluation of Brazilian sugarcane expansion on soil quality. Soil
Sci Soc Am J 80:215-226. https://doi.org/10.2136/sssaj2015.09. 0328

Christofoletti CA, Escher JP, Correia JE, Marinho JFU, Fontanetti CS (2013) Sugarcane vinasse: environmental implications of its use. Waste Manag 33:2752-2761. https://doi.org/10.1016/j.wasman. 2013.09.005

Chum HL, Warner E, Seabra JEA, Macedo IC (2014) A comparison of commercial ethanol production systems from Brazilian sugarcane and US corn. Biofuels Bioprod Biorefin 8:205-223. https://doi. org $/ 10.1002 / b b b .1448$

CONAB (2017) Companhia Nacional de Abastecimento. Acompanhamento da safra brasileira de cana-de-açúcar. Primeiro Levantamento-Safra 2017/18, 62p. http:/www.conab.gov.br. Accessed 13 July 17

Costa FP, Rehman T (1999) Exploring the link between farmers' objectives and the phenomenon of pasture degradation in the beef production systems of Central Brazil. Agric Syst 61:135-146. https:// doi.org/10.1016/S0308-521X(99)00043-8

Costa MCG, Vitti GC, Cantarella H (2003) Volatilização de $\mathrm{N}_{-N_{3}}$ de fontes nitrogenadas em cana-de-açúcar colhida sem despalha a fogo. Rev Bras Ci Solo 27:631-637. https://doi.org/10.1590/S010006832003000400007

Crews TE, Peoples MB (2004) Legume versus fertilizer sources of nitrogen: ecological tradeoffs and human needs. Agric Ecosyst Environ 102:279-297. https://doi.org/10.1016/j.agee.2003.09.018

Da Silva CRU, Franco HCJ, Junqueira TL, van Oers L, van der Voet E, Seabra JEA (2014a) Long-term prospects for the environmental profile of advanced sugar cane ethanol. Environ Sci Technol 48: 12394-12402. https://doi.org/10.1021/es502552f

Da Silva GRV, De Souza ZM, Martins Filho MV, Barbosa RS, De Souza GS (2012) Soil, water and nutrient losses by interrill erosion from green cane cultivation. Rev Bras Cienc Solo 36:963-970. https:// doi.org/10.1590/S0100-06832012000300026

Da Silva WP, de Almeida CDGC, Rolim MM, Silva ÊFF, Pedrosa EMR, Silva VGF (2014b) Monitoramento da salinidade de águas subterrâneas em várzea cultivada com cana-de-açúcar fertirrigada com vinhaça. Rev Bras Eng Agric Ambient 18:394-401. https:// doi.org/10.1590/S1415-43662014000400006

Dale BE, Bals BD, Kim S, Eranki P (2010) Biofuels done right: land efficient animal feeds enable large environmental and energy benefits. Environ Sci Technol 44:8385-8389. https://doi.org/10.1021/ es $101864 b$

Davis SC, Anderson-Teixeira KJ, DeLucia EH (2009) Life-cycle analysis and the ecology of biofuels. Trends Plant Sci 14:140-146. https:// doi.org/10.1016/j.tplants.2008.12.006

Davis SC, Boddey RM, Alves BJR, Cowie AL, George BH, Ogle SM, Smith P, van Noordwijk M, van Wijk MT (2013) Management swing potential for bioenergy crops. Glob Change Biol Bioenergy 5:623-638. https://doi.org/10.1111/gcbb. 12042

De Figueiredo EB, Jayasundara S, de Oliveira BR, Berchielli TT, Reis RA, Wagner-Riddle C, La Scala JN (2017) Greenhouse gas balance and carbon footprint of beef cattle in three contrasting pasturemanagement systems in Brazil. J Clean Prod 142:420-431. https:// doi.org/10.1016/j.jclepro.2016.03.132

De Figueiredo EB, La Scala N Jr (2011) Greenhouse gas balance due to the conversion of sugarcane areas from burned to green harvest in Brazil. Agric Ecosyst Environ 141:77-85. https://doi.org/10.1016/j. agee.2011.02.014

De Figueiredo EB, Panosso AR, Reicosky DC, La Scala N (2015) Shortterm $\mathrm{CO}_{2}-\mathrm{C}$ emissions from soil prior to sugarcane (Saccharum spp.) replanting in southern Brazil. Glob Change Biol Bioenergy 7:316-327. https://doi.org/10.1111/gcbb.12151

De Luca EF, Feller C, Cerri CC, Barthes B, Chaplot V (2008) Evaluation of physical properties and soil carbon and nitrogen stocks as affected by burning or green trash management of sugarcane. Rev Bras Cienc 
Solo 32:789-800. https://doi.org/10.1590/S010006832008000200033

De Moraes MMGA, Cai X, Ringler C, Albuquerque BE, da Rocha SPV, Amorim CA (2010) Joint water quantity-quality management in a biofuel production area - integrated economic-hydrologic modeling analysis. J Water Resour Plan Manage 136:502-511. https://doi.org/ 10.1061/(ASCE)WR.1943-5452.0000049

De Souza GS, De Souza ZM, Da Silva RB, Araújo FS, Barbosa RS (2012) Compressibilidade do solo e sistema radicular da cana de açúcar em manejo com e sem controle de tráfego. Pesq Agropec Bras 47:603-612. https://doi.org/10.1590/S0100204X2012000400017

Delgado JA, Groffman PM, Nearing MA, Goddard T, Reicosky D, Lal R, Kitchen NR, Rice CW, Towery D, Salon P (2011) Conservation practices to mitigate and adapt to climate change. J Soil Water Conserv 66:118A-129A. https://doi.org/10.2489/jswc.66.4.118A

Derpsch R, Franzluebbers AJ, Duiker SW, Reicosky DC, Koeller K, Friedrich T, Sturny WG, Sá JCM, Weiss K (2014) Why do we need to standardize no-tillage research? Soil Till Res 137:16-22. https:// doi.org/10.1016/j.still.2013.10.002

Dimitriou I, Baum C, Baum S et al (2011) Quantifying environmental effects of short rotation coppice (SRC) on biodiversity, soil and water. IEA Bioenergy: Task 43. http://ieabioenergytask43.org/wpcontent/uploads/2013/09/IEA_Bioenergy_Task43_TR2011-01.pdf. Accessed 18 April 2015

Dinardo-Miranda LL, Fracasso JV (2013) Sugarcane straw and the populations of pests and nematodes. Sci Agric 70:305-310. https://doi. org/10.1590/S0103-90162013000500012

Dourado Neto D, Powlson D, Abu Bakar R, Bacchi OOS, Basanta MV, Thi Cong P, Keerthisinghe S, Ismaili M, Rahman SM, Reichardt K, Safwat MSA, Sangakkara R, Timm LC, Wang JY, Zagal E, Van Kessel C (2010) Multiseason recoveries of organic and inorganic nitrogen-15 in tropical cropping systems. Soil Sci Soc Am J 74:139 152. https://doi.org/10.2136/sssaj2009.0192

Dunn JB, Mueller S, H-y K, Wang MQ (2013) Land-use change and greenhouse gas emissions from corn and cellulosic ethanol. Biotechnol Biofuels 6:51. https://doi.org/10.1186/1754-6834-6-51

Egeskog A, Berndes G, Freitas F, Gustafsson S, Sparovek G (2011) Integrating bioenergy and food production - a case study of combined ethanol and dairy production in Pontal, Brazil. Energy Sustain Dev 15:8-16. https://doi.org/10.1016/j.esd.2011.01.005

Egeskog A, Freitas F, Berndes G, Sparovek G, Wirsenius S (2014) Greenhouse gas balances and land use changes associated with the planned expansion (to 2020) of the sugarcane ethanol industry in Sao Paulo, Brazil. Biomass Bioenergy 63:280-290. https://doi.org/ 10.1016/j.biombioe.2014.01.030

FAOSTAT (2017) Food and agriculture organization of the United Nations. Statistics Division. http://www.fao.org/faostat/en/\#data. Accessed 10 July 2017

Fargione J, Hill J, Tilman D, Polasky S, Hawthorne P (2008) Land clearing and the biofuel carbon debt. Science 319:1235-1238. https://doi. org/10.1126/science. 1152747

Farrell AE, Plevin RJ, Turner BT, Jones AD, O'Hare M (2006) Ethanol can contribute to energy and environmental goals. Science 311:506508. https://doi.org/10.1126/science.1121416

Ferreira ASG, Silva HCMP, Rodrigues HOS, Silva M, Albuquerque Junior EC (2016) Occurrence and spatial-temporal distribution of herbicide residues in the Ipojuca River sub-basin, Pernambuco, Brazil. Rev Bras Eng Agric Ambient 20:1124-1128. https://doi. org/10.1590/1807-1929/agriambi.v20n12p1124-1128

Ferreira Filho JBS, Horridge M (2014) Ethanol expansion and indirect land use change in Brazil. Land Use Policy 36:595-604. https://doi. org/10.1016/j.landusepol.2013.10.015

Ferrera Filho JBS (2013) Food security, the labor market, and poverty in the Brazilian bio-economy. Agric Econ 44:85-93. https://doi.org/10. 1111/agec. 12053
Filoso S, Antonio Martinelli L, Howarth RW, Boyer EW, Dentener F (2006) Human activities changing the nitrogen cycle in Brazil. Biogeochemistry 79:61-89. https://doi.org/10.1007/s10533-0069003-0

Filoso S, Carmo JB, Mardegan SF, Lins SRM, Gomes TF, Martinelli LA (2015) Reassessing the environmental impacts of sugarcane ethanol production in Brazil to help meet sustainability goals. Renew Sust Energ Rev 52:1847-1856. https://doi.org/10.1016/j.rser.2015.08. 012

Franco ALC, Bartz MLC, Cherubin MR, Baretta D, Cerri CEP, Feigl BJ, Wall DH, Davies CA, Cerri CC (2016) Loss of soil (macro) fauna due to the expansion of Brazilian sugarcane acreage. Sci Total Environ 563:160-168. https://doi.org/10.1016/j.scitotenv.2016.04. 116

Franco HCJ, Otto R, Faroni CE, Vitti AC, Almeida de Oliveira EC, Trivelin PCO (2011) Nitrogen in sugarcane derived from fertilizer under Brazilian field conditions. Field Crops Res 121:29-41. https:// doi.org/10.1016/j.fcr.2010.11.011

Fuess LT, Garcia ML (2014) Implications of stillage land disposal: a critical review on the impacts of fertigation. J Environ Manag 145: 210-229. https://doi.org/10.1016/j.jenvman.2014.07.003

Galdos M, Cavalett O, Seabra JEA, Horta Nogueira LA, Bonomi A (2013) Trends in global warming and human health impacts related to Brazilian sugarcane ethanol production considering black carbon emissions. Appl Energy 104:576-582. https://doi.org/10.1016/j. apenergy.2012.11.002

Galdos MV, Cerri CC, Cerri CEP (2009) Soil carbon stocks under burned and unburned sugarcane in Brazil. Geoderma 153:347-352. https:// doi.org/10.1016/j.geoderma.2009.08.025

García CA, Fuentes A, Hennecke A, Riegelhaupt E, Manzini F, Masera O (2011) Life-cycle greenhouse gas emissions and energy balances of sugarcane ethanol production in Mexico. Appl Energy 88:20882097. https://doi.org/10.1016/j.apenergy.2010.12.072

Gauder M, Graeff-Hönninger S, Claupein W (2011) The impact of a growing bioethanol industry on food production in Brazil. Appl Energy 88:672-679. https://doi.org/10.1016/j.apenergy.2010.08. 020

Gava GJC, Trivelin PCO, Oliveira MW, Penatti CP (2001) Crescimento e acúmulo de nitrogênio em cana-de-açúcar cultivada em solo coberto com palhada. Pesq Agrop Bras 36:347-1354. https://doi.org/10. 1590/S0100-204X2001001100004

Gerbens-Leenes W, Hoekstra AY, van der Meer TH (2009) The water footprint of bioenergy. Proc Natl Acad Sci U S A 106:10219-10223. https://doi.org/10.1073/pnas.0812619106

Ghiberto PJ, Libardi PL, Brito AS, Trivelin PCO (2009) Leaching of nutrients from a sugarcane crop growing on an Ultisol in Brazil. Agric Water Manag 96:1443-1448. https://doi.org/10.1016/j. agwat.2009.04.020

Ghiberto PJ, Libardi PL, Brito AS, Trivelin PCO (2011) Components of the water balance in soil with sugarcane crops. Agric Water Manag 102:1-7. https://doi.org/10.1016/j.agwat.2011.09.010

Ghiberto PJ, Libardi PL, Trivelin PCO (2015) Nutrient leaching in an Ultisol cultivated with sugarcane. Agric Water Manag 31:141-149. https://doi.org/10.1016/j.agwat.2014.09.027

Gibbs HK, Johnston M, Foley JA, Holloway T, Monfreda C (2008) Carbon payback times for crop-based biofuel expansion in the tropics: the effects of changing yield and technology. Environ Res Lett 3:034001. https://doi.org/10.1088/1748-9326/3/3/034001

Goldemberg J (2007) Ethanol for a sustainable energy future. Science 315:808-810. https://doi.org/10.1126/science.1137013

Goldemberg J, Guardabassi P (2010) The potential for first-generation ethanol production from sugarcane. Biofuels Bioprod Biorefin 4: 17-24. https://doi.org/10.1002/bbb.186

Goldemberg J, Mello FFC, Cerri CEP, Davies CA, Cerri CC (2014) Meeting the global demand for biofuels in 2021 through sustainable 
land use change policy. Energy Policy 69:14-18. https://doi.org/10. 1016/j.enpol.2014.02.008

Guarenghi MM, Walter A (2016) Assessing potential impacts of sugarcane production on water resources: a case study in Brazil. Biofuels Bioprod Biorefin 10:699-709. https://doi.org/10.1002/bbb.1680

Hartemink AE (2008) Sugarcane for bioethanol: soil and environmental issues. In: Sparks DL (ed) Advances in agronomy. Academic Press, London, pp 125-182

Hassuani SJ, Leal MRLV, Macedo IC (2005) Biomass power generation: sugarcane bagasse and trash, Série Caminhos para Sustentabilidade. PNUD-CTC, Piracicaba/SP. https://pdfs.semanticscholar.org/1c8f/ cebf7aef193b4f9a0de509f9ed84d84bdf9a.pdf Accessed 22 July 2017

Hemwong S, Toomsan B, Cadisch G, Limpinuntana V, Vityakon P (2009) Sugarcane residue management and grain legume crop effects on $\mathrm{N}$ dynamics, $\mathrm{N}$ losses and growth of sugarcane. Nutr Cycl Agroecosys 83:135-151. https://doi.org/10.1007/s10705-008-92098

Hernandes TAD, Bufon VB, Seabra JEA (2014) Water footprint of biofuels in Brazil: assessing regional differences. Biofuels Bioprod Biorefin 8:241-252. https://doi.org/10.1002/bbb.1454

Hess TM, Sumberg J, Biggs T, Georgescu M, Haro-Monteagudo D, Jewitt G, Ozdogan M, Marshall M, Thenkabail P, Daccache A, Marin F, Knox JW (2016) A sweet deal? Sugarcane, water and agricultural transformation in Sub-Saharan Africa. Glob Environ Chang 39:181-194. https://doi.org/10.1016/j.gloenvcha.2016.05. 003

Hoefsloot G, Termorshuizen AJ, Watt DA, Cramer MD (2005) Biological nitrogen fixation is not a major contributor to the nitrogen demand of a commercially grown South African sugarcane cultivar. Plant Soil 277:85-96. https://doi.org/10.1007/s11104-005-2581-0

IBGE (2017) Instituto Brasileiro de Geografia e Estatística. Levantamento sistemático da produção agrícola, Pesquisa mensal de previsão e acompanhamento das safras agrícola - Maio 2017. http://www.ibge.gov.br. Accessed 20 July 2017

iNDC Brazil (2015) Intended nationally determined contribution towards achieving the objective of the United Nations Framework Convention on Climate Change. Federative Republic of Brazil. http://www.itamaraty.gov.br/images/ed desenvsust/BRAZILiNDC-english.pdf. Accessed 25 July 2017

IPCC (2006) Guidelines for National Greenhouse Gas Inventories. In: Eggleston, S., Buendia, L., Miwa, K., Ngara, T., Tanabe, K. (Eds.), IPCC National Greenhouse Gas Inventories Programme. Institute for Global Environmental Strategies (IGES), Hayama, Japan, 664p

IPCC (2013) Climate change 2013: the physical science basis. Contribution of Working Group I to the Fifth Assessment Report of the Intergovernmental Panel on Climate Change. Cambridge University Press, Cambridge, United Kingdom and New York, NY, USA

Jacomini AE, de Camargo PB, Avelar WEP, Bonato PS (2011) Assessment of ametryn contamination in river water, river sediment, and mollusk bivalves in São Paulo State, Brazil. Arch Environ Contam Toxicol 60:452-461. https://doi.org/10.1007/s00244-0109552-z

James EK, Baldani JI (2012) The role of biological nitrogen fixation by non-legumes in the sustainable production of food and biofuels. Plant Soil 356:1-3. https://doi.org/10.1007/s11104-012-1317-1

Jensen ES, Peoples MB, Boddey RM, Gresshoff PM, Hauggaard-Nielsen $\mathrm{H}$ (2012) Legumes for mitigation of climate change and the provision of feedstock for biofuels and biorefineries. A review. Agron Sustain Dev 32:329-364. https://doi.org/10.1007/s13593-0110056-7

Johnston M, Licker R, Foley J, Holloway T, Mueller ND (2011) Closing the gap: global potential for increasing biofuel production through agricultural intensification. Environ Res Lett 6:034028. https://doi. org/10.1088/1748-9326/6/3/034028

Koçar G, Civaș N (2013) An overview of biofuels from energy crops: current status and future prospects. Renew Sust Energ Rev 28:900 916. https://doi.org/10.1016/j.rser.2013.08.022

Kumar V, Wati L, Nigam P, Banat IM, Yadav BS, Singh D, Marchant R (1998) Decolorization and biodegradation of anaerobically digested sugarcane molasses spent wash effluent from biomethanation plants by white-rot fungi. Process Biochem 33:83-88. https://doi.org/10. 1016/S0032-9592(97)00047-2

La Scala N Jr, Bolonhezi D, Pereira GT (2006) Short-term soil CO2 emission after conventional and reduced tillage of a no-till sugar cane area in southern Brazil. Soil Till Res 91:244-248. https://doi. org/10.1016/j.still.2005.11.012

La Scala N Jr, De Figueiredo EB, Panosso AR (2012) A review on soil carbon accumulation due to the management change of major Brazilian agricultural activities. Braz J Biol 72:775-785. https:// doi.org/10.1590/S1519-69842012000400012

La Scala N Jr, Lopes A, Spokas K, Bolonhezi D, Archer DW, Reicosky DC (2008) Short-term temporal changes of soil carbon losses after tillage described by a first-order decay model. Soil Till Res 99:108118. https://doi.org/10.1016/j.still.2008.01.006

Lal R (2004) Carbon emission from farm operations. Environ Int 30:981990. https://doi.org/10.1016/j.envint.2004.03.005

Lal R (2006) Enhancing crop yields in the developing countries through restoration of the soil organic carbon pool in agricultural lands. Land Degrad Dev 17:197-209. https://doi.org/10.1002/ldr.696

Lal R (2013) Food security in a changing climate. Ecohydrol Hydrobiol 13:8-21. https://doi.org/10.1016/j.ecohyd.2013.03.006

Lal R (2014) Biofuels and carbon offsets. Biofuels 5:21-27. https://doi. org $/ 10.4155 / \mathrm{bfs} .13 .62$

Lal R, Delgado JA, Groffman PM, Millar N, Dell C, Rotz A (2011) Management to mitigate and adapt to climate change. J Soil Water Conserv 66:276-285. https://doi.org/10.2489/jswc.66.4.276

Lapola DM, Martinelli LA, Peres CA, Ometto JPHB, Ferreira ME (2013) Pervasive transition of the Brazilian land-use system. Nat Clim Chang 4:27-35. https://doi.org/10.1038/nclimate2056

Lapola DM, Schaldach R, Alcamo J, Bondeau A, Koch J, Koelking C, Priess JA (2010) Indirect land-use changes can overcome carbon savings from biofuels in Brazil. Proc Natl Acad Sci U S A 107: 3388-3393. https://doi.org/10.1073/pnas.0907318107

Larson ED (2006) A review of life-cycle analysis studies on liquid biofuel systems for the transport sector. Energy Sustain Dev 10:109-126. https://doi.org/10.1016/S0973-0826(08)60536-0

Leal MRLV, Galdos MV, Scarpare FV, Seabra JEA, Walter A (2013a) Sugarcane straw availability, quality, recovery and energy use: a literature review. Biomass Bioenergy 53:11-19. https://doi.org/10. 1016/j.biombioe.2013.03.007

Leal MRLV, Horta Nogueira LA, Cortez LAB (2013b) Land demand for ethanol production. Appl Energy 102:266-271. https://doi.org/10. 1016/j.apenergy.2012.09.037

Lisboa CC, Butterbach-Bahl K, Mauder M, Kiese R (2011) Bioethanol production from sugarcane and emissions of greenhouse gasesknown and unknowns. Glob Change Biol Bioenergy 3:277-292. https://doi.org/10.1111/j.1757-1707.2011.01095.x

Lisboa IP, Cherubin MR, Cerri CC, Cerri DGP, Cerri CEP (2017) Guidelines for the recovery of sugarcane straw from the field during harvesting. Biomass Bioenergy 96:69-74. https://doi.org/10.1016/j. biombioe.2016.11.008

Loarie SR, Lobell DB, Asner GP, Mu Q, Field CB (2011) Direct impacts on local climate of sugar-cane expansion in Brazil. Nat Clim Chang 1:105-109. https://doi.org/10.1038/nclimate1067

Lybbert TJ, Sumner DA (2012) Agricultural technologies for climate change in developing countries: policy options for innovation and technology diffusion. Food Policy 37:114-123. https://doi.org/10. 1016/j.foodpol.2011.11.001 
Lynd LR, Woods J (2011) Perspective: a new hope for Africa. Nature 474:S20-S21. https://doi.org/10.1038/474S020a

Macedo IC (2005). Sugar cane's energy: twelve studies on Brazilian sugar cane agribusiness and its sustainability. 2nd edn, União da Agroindústria Canavieira do Estado de São Paulo (UNICA), São Paulo/SP, 233p

Macedo IC, Seabra JEA, Silva JEAR (2008) Green house gases emissions in the production and use of ethanol from sugarcane in Brazil: the $2005 / 2006$ averages and a prediction for 2020 . Biomass Bioenergy 32:582-595. https://doi.org/10.1016/j.biombioe.2007. 12.006

Magalhães PSG, Nogueira LAH, Cantarella H, Rossetto R, Franco HCJ, Braunbeck OA (2012) Agro-industrial technological paths. In: Sustainability of sugarcane bioenergy by Center of Strategic Studies and Management. CGEE, Brasília/DF, pp 27-69

Malezieux E, Crozat Y, Dupraz C, Laurans M, Makowski D (2009) Mixing plant species in cropping systems: concepts, tools and models. A review. Agron Sustain Dev 29:43-62. https://doi.org/ 10.1051/agro:2007057

Manochio C, Andrade BR, Rodriguez RP, Moraes BS (2017) Ethanol from biomass: a comparative overview. Renew Sust Energ Rev 80:743-755. https://doi.org/10.1016/j.rser.2017.05.063

Manzatto CV, Assad ED, Bacca JFM, Zaroni MJ, Pereira SEM (2009) Zoneamento Agroecológico da Cana-de-Açúcar-Expandir a produção, preservar a vida, garantir o futuro. Documentos 110 , Embrapa Solos, Rio de Janeiro/RJ, 55p

Mariano E, Trivelin PCO, Vieira MX, Leite JM, Otto R, Franco HCJ (2012) Ammonia losses estimated by an open collector from urea applied to sugarcane straw. Rev Bras Ci Solo 36:411-419. https:// doi.org/10.1590/S0100-06832012000200010

Marin FR, Martha GB, Cassman KG, Grassini P (2016) Prospects for increasing sugarcane and bioethanol production on existing crop area in Brazil. Bio Science 66:307-316. https://doi.org/10.1093/ biosci/biw009

Martins Filho MV, Liccioti TT, Pereira GT, Marques Júnior J, Sanchez RB (2009) Perdas de solo e nutrientes por erosão num Argissolo com resíduos vegetais de cana-de-açúcar. Eng Agric 29:8-18. https://doi.org/10.1590/S0100-69162009000100002

Mathews JA (2007) Biofuels: what a biopact between north and south could achieve. Energy Policy 35:3550-3570. https://doi.org/10. 1016/j.enpol.2007.02.011

McManus C, Barcellos JOJ, Formenton BK, Hermuche PM, Carvalho OA, Guimarães RF, Gianezini M, Dias EA, Lampert VN, Zago D, Neto JB (2016) Dynamics of cattle production in Brazil. PLoS One 11:e 0147138. https://doi.org/10.1371/journal.pone.0147138

MCTI (2010) Ministério da Ciência, Tecnologia e Inovação. Segunda Comunicação Nacional do Brasil à Convenção-Quadro das Nações Unidas sobre Mudança do Clima. http://www.mct.gov.br/ index.php/content/view/326988.html. Accessed 18 May 2016

MCTI (2014) Ministério da Ciência, Tecnologia e Inovação. Estimativas anuais de emissões de gases de efeito estufa no Brasil. 2nd edn, Brasília, Brasil. http://www.mct.gov.br/upd_blob/0235/235580.pdf. Accessed 09 June 2016

Medeiros AFA, Polidoro JC, Reis VM (2006) Nitrogen source effect on Gluconacetobacter diazotrophicus colonization of sugarcane (Saccharum Spp.) Plant Soil 279:141-152. https://doi.org/10.1007/ s11104-005-0551-1

Mekonnen MM, Hoekstra AY (2011) The green, blue and grey water footprint of crops and derived crop products. Hydrol Earth Syst Sci 15:1577-1600. https://doi.org/10.5194/hess-15-1577-2011

Menandro LMS, Cantarella H, Franco HCJ, Kölln OT, Pimenta MTB, Sanches GM, Rabelo SC, Carvalho JLN (2017) Comprehensive assessment of sugarcane straw: implications for biomass and bioenergy production. Biofuels Bioprod Biorefin 11:488-504. https://doi.org/10.1002/bbb.1760
Mello FFC, Cerri CEP, Davies CA, Holbrook NM, Paustian K, Maia SMF, Galdos MV, Bernoux M, Cerri CC (2014) Payback time for soil carbon and sugar-cane ethanol. Nat Clim Chang 4:605-609. https://doi.org/10.1038/nclimate2239

MME (2017) Ministry of Mines and Energy. Renova Bio Programme. http://www.mme.gov.br/web/guest/secretarias/petroleo-gas-naturale-combustiveis-renovaveis/programas/renovabio/principal. Accessed 26 July 2017

Moitinho MR, Padovan MP, Panosso AR, La Scala JN (2013) Efeito do preparo do solo e resíduo da colheita de cana-de-açúcar sobre a emissão de $\mathrm{CO}_{2}$. Rev Bras Cienc Solo 37:1720-1728. https://doi. org/10.1590/S0100-06832013000600028

Moraes BS, Petersen SO, Zaiat M, Sommer SG, Triolo JM (2017) Reduction in greenhouse gas emissions from vinasse through anaerobic digestion. Appl Energy 189:21-30. https://doi.org/10.1016/j. apenergy.2016.12.009

Muñoz I, Flury K, Jungbluth N, Rigarlsford G, Canals L, King H (2014) Life cycle assessment of bio-based ethanol produced from different agricultural feedstocks. Int J Life Cycle Assess 19:109-119. https:// doi.org/10.1007/s11367-013-0613-1

Nepstad D, McGrath D, Stickler C, Alencar A, Azevedo A (2014) Slowing Amazon deforestation through public policy and interventions in beef and soy supply chains. Science 344:1118-1123. https:// doi.org/10.1126/science. 1248525

Nguyen TLT, Gheewala SH, Sagisaka M (2010) Greenhouse gas savings potential of sugar cane bio-energy systems. J Clean Prod 18:412418. https://doi.org/10.1016/j.jclepro.2009.12.012

Nogueira LAH, Capaz RS (2013) Biofuels in Brazil: evolution, achievements and perspectives on food security. Glob Food Sec 2:117-125. https://doi.org/10.1016/j.gfs.2013.04.001

Oliveira BG, Carvalho JLN, Cerri CEP, Cerri CC, Feigl BJ (2013) Soil greenhouse gas fluxes from vinasse application in Brazilian sugarcane areas. Geoderma 200-201:77-84. https://doi.org/10.1016/j. geoderma.2013.02.005

Oliveira BG, Carvalho JLN, Pellegrino Cerri CE, Cerri CC, Feigl BJ (2015) Greenhouse gas emissions from sugarcane vinasse transportation by open channel: a case study in Brazil. J Clean Prod 94:102107. https://doi.org/10.1016/j.jclepro.2015.02.025

Oliveira BG, Carvalho JLN, Chagas MF, Cerri CEP, Cerri CC, Feigl BJ (2017b) Methane emissions from sugarcane vinasse storage and transportation systems: comparison between open channels and tanks. Atmos Environ 159:135-146. https://doi.org/10.1016/j. atmosenv.2017.04.005

Oliveira DMS, Paustian K, Davies CA, Cherubin MR, Franco ALC, Cerri CC, Cerri CEP (2016) Soil carbon changes in areas undergoing expansion of sugarcane into pastures in south-central Brazil. Agric Ecosyst Environ 228:38-48. https://doi.org/10.1016/j.agee.2016.05. 005

Oliveira DMS, Williams S, Cerri CEP, Paustian K (2017a) Predicting soil $\mathrm{C}$ changes over sugarcane expansion in Brazil using the Day Cent model. Glob Change Biol Bioenergy. https://doi.org/10.1111/gcbb. 12427

Oliveira MW, Trivelin PCO, Boaretto AE, Muraoka T, Mortatti J (2002) Leaching of nitrogen, potassium, calcium and magnesium in a sandy soil cultivated with sugarcane. Pesq Agropec Bras 37:861-868. https://doi.org/10.1590/S0100-204X2002000600016

Ometto AR, Hauschild MZ, Roma WNL (2009) Lifecycle assessment of fuel ethanol from sugarcane in Brazil. Int J Life Cycle Assess 14: 236-247. https://doi.org/10.1007/s11367-009-0065-9

Otto R, Castro SAQ, Mariano E, Castro SGQ, Franco HCJ, Trivelin PCO (2016) Nitrogen use efficiency for sugarcane-biofuel production: what is next? Bio Energy Res 9:1272-1289. https://doi.org/10. 1007/s12155-016-9763-x

Otto R, Freitas Júnior JCM, Zavaschi E, Faria IKP, Paiva LA, Bazani JH, Mira AB, Kamogawa MY (2017) Combined application of concentrated vinasse and nitrogen fertilizers in sugarcane: strategies to 
reduce ammonia volatilization losses. Sugar Tech 19:248-257. https://doi.org/10.1007/s12355-016-0463-9

Otto R, Mulvaney RL, Khan SA, Trivelin PCO (2013) Quantifying soil nitrogen mineralization to improve fertilizer nitrogen management of sugarcane. Biol Fertil Soils 49:893-904. https://doi.org/10.1007/ s00374-013-0787-5

Otto R, Silva AP, Franco HCJ, Oliveira ECA, Trivelin PCO (2011) High soil penetration resistance reduces sugarcane root system development. Soil Till Res 117:201-210. https://doi.org/10.1016/j.still. 2011.10.005

Paredes DS, Lessa ACR, de Sant'Anna SAC, Boddey RM, Urquiaga S (2014) Nitrous oxide emission and ammonia volatilization induced by vinasse and $\mathrm{N}$ fertilizer application in a sugarcane crop at Rio de Janeiro, Brazil. Nutr Cycl Agroecosys 98:41-55. https://doi.org/10. 1007/s10705-013-9594-5

Park SE, Webster TJ, Horan HL, James AT, Thorburn PJ (2010) A legume rotation crop lessens the need for nitrogen fertiliser throughout the sugarcane cropping cycle. Field Crops Res 119:331-341. https:// doi.org/10.1016/j.fcr.2010.08.001

Parnaudeau V, Condom N, Oliver R, Cazevieille P, Recous S (2008) Vinasse organic matter quality and mineralization potential, as influenced by raw material, fermentation and concentration processes. Bioresour Technol 99:1553-1562. https://doi.org/10.1016/j. biortech.2007.04.012

Peoples MB, Herridge DF, Ladha JK (1995) Biological nitrogen fixation: an efficient source of nitrogen for sustainable agricultural production? Plant Soil 174:3-28. https://doi.org/10.1007/BF00032239

Pereira CLF, Ortega E (2010) Sustainability assessment of large-scale ethanol production from sugarcane. J Clean Prod 18:77-82. https://doi.org/10.1016/j.jclepro.2009.09.007

Pinheiro ÉFM, Lima E, Ceddia MB, Urquiaga S, Alves BJR (2010) Impact of pre-harvest burning versus trash conservation on soil carbon and nitrogen stocks on a sugarcane plantation in the Brazilian Atlantic forest region. Plant Soil 333:71-80. https://doi.org/10.1007/ s11104-010-0320-7

Pitombo LM, do Carmo JB, de Hollander M, Rossetto R, López MV, Cantarella H, Kuramae EE (2016) Exploring soil microbial 16S rRNA sequence data to increase carbon yield and nitrogen efficiency of a bioenergy crop. Glob Change Biol Bioenergy 8:867-879. https://doi.org/10.1111/gcbb.12284

Popp J, Lakner Z, Harangi-Rákos M, Fári M (2014) The effect of bioenergy expansion: food, energy, and environment. Renew Sust Energ Rev 32:559-578. https://doi.org/10.1016/j.rser.2014.01.056

Powlson DS, Stirling CM, Jat ML, Gerard BG, Palm CA, Sanchez PA, Cassman KG (2014) Limited potential of no-till agriculture for climate change mitigation. Nat Clim Chang 4:678-683. https://doi.org/ 10.1038/nclimate2292

Prasertsak P, Freney DOT, Saffigna PG, Prove BG (2002) Effect of fertilizer placement on nitrogen loss from sugarcane in tropical Queensland. Nutr Cycl Agroecosys 62:229-239. https://doi.org/10. 1023/A:1021279309222

Ramburan S, Nxumalo N (2017) Regional, seasonal, cultivar and cropyear effects on sugarcane responses to residue mulching. Field Crops Res 210:136-146. https://doi.org/10.1016/j.fcr.2017.06.001

Reay DS, Davidson EA, Smith KA, Smith P, Melillo JM, Dentener F, Crutzen PJ (2012) Global agriculture and nitrous oxide emissions. Nat Clim Chang 2:410-416. https://doi.org/10.1038/nclimate1458

Renouf MA, Wegener MK, Nielsen LK (2008) An environmental life cycle assessment comparing Australian sugarcane with US corn and UK sugar beet as producers of sugars for fermentation. Biomass Bioenergy 32:1144-1155. https://doi.org/10.1016/j. biombioe.2008.02.012

Resende AS, Xavier RP, de Oliveira OC, Urquiaga S, Alves BJR, Boddey RM (2006) Long-term effects of pre-harvest burning and nitrogen and vinasse applications on yield of sugar cane and soil carbon and nitrogen stocks on a plantation in Pernambuco, N.E. Brazil. Plant Soil 281:339-351. https://doi.org/10.1007/s11104-005-4640-y

RFA (2016) Renewable fuels association. Fueling a high octane future: ethanol industry outlook. http://ethanolrfa.org/wp-content/uploads/ 2016/02/RFA 2016 full final.pdf. Accessed 17 Sept 2017

Robertson FA, Thorburn PJ (2007) Management of sugarcane harvest residues: consequences for soil carbon and nitrogen. Aust J Soil Res 45:13-23. https://doi.org/10.1071/SR06080

Robinson N, Brackin R, Soper KVF, Gamage JHH, Paungfoo-Lonhienne C, Rennenberg H, Lakshmanan P, Schmidt S (2011) Nitrate paradigm does not hold up for sugarcane. PLoS One 6:e19045. https:// doi.org/10.1371/journal.pone.0019045

Rocha MH, Capaz RS, Lora EES, Nogueira LAH, Leme MMV, Renó MLG, Olmo OA (2014) Life cycle assessment (LCA) for biofuels in Brazilian conditions: a meta-analysis. Renew Sust Energ Rev 37: 435-459. https://doi.org/10.1016/j.rser.2014.05.036

Rochette P, Janzen HH (2005) Towards a revised coefficient for estimating $\mathrm{N}_{2} \mathrm{O}$ emissions from legumes. Nutr Cycl Agroecosys 73:171179. https://doi.org/10.1007/s10705-005-0357-9

Rockström J, Karlberg L, Wani SP, Barron J, Hatibu N, Oweis T, Bruggeman A, Farahani J, Qiang Z (2010) Managing water in rainfed agriculture - the need for a paradigm shift. Agric Water Manag 97:543-550. https://doi.org/10.1016/j.agwat.2009.09.009

Rossetto R, Cantarella H, Dias FLF, Landell MGA, Vitti AC (2008) Manejo conservacionista e reciclagem de nutrientes em cana-deaçúcar tendo em vista a colheita mecânica. Informações Agronômicas 124:8-13

Scarpare FV, Hernandes TAD, Ruiz-Corrêa ST, Picoli MCA, Scanlon BR, Chagas MF, Duft DG, Cardoso TF (2016a) Sugarcane land use and water resources assessment in the expansion area in Brazil. J Clean Prod 133:1318-1327. https://doi.org/10.1016/j. jclepro.2016.06.074

Scarpare FV, Hernandes TAD, Ruiz-Corrêa ST, Kolln OT, Gava GJC, dos Santos LNS, Victoria RL (2016b) Sugarcane water footprint under different management practices in Brazil: Tietê/Jacaré watershed assessment. J Clean Prod 112:4576-4584. https://doi.org/10.1016/ j.jclepro.2015.05.107

Schmidhuber J, Tubiello FN (2007) Global food security under climate change. Proc Natl Acad Sci U S A 104:19703-19708. https://doi. org/10.1073/pnas.0701976104

Seabra JEA, Macedo IC, Chum HL, Faroni CE, Sarto CA (2011) Life cycle assessment of Brazilian sugarcane products: GHG emissions and energy use. Biofuels Bioprod Biorefin 5:519-532. https://doi. org/10.1002/bbb.289

Searchinger T, Edwards R, Mulligan D, Heimlich R, Plevin R (2015) Do biofuel policies seek to cut emissions by cutting food? Science 347: 1420-1422. https://doi.org/10.1126/science.1261221

Searchinger T, Heimlich R, Houghton RA, Dong F, Elobeid A (2008) Use of U.S. croplands for biofuels increases greenhouse gases through emissions from land-use change. Science 319:1238-1240. https:// doi.org/10.1126/science. 1151861

Segnini A, Carvalho JLN, Bolonhezi D, Milori DMBP, Silva WTL, Simões ML, Cantarella H, Maria IC, Martin-Neto L (2013) Carbon stock and humification index of organic matter affected by sugarcane straw and soil management. Sci Agric 70:321-326. https://doi.org/10.1590/S0103-90162013000500006

Signor D, Cerri CEP, Conant R (2013) $\mathrm{N}_{2} \mathrm{O}$ emissions due to nitrogen fertilizer applications in two regions of sugarcane cultivation in Brazil. Environ Res Lett 8:015013. https://doi.org/10.1088/17489326/8/1/015013

Silva DAL, Delai I, Montes MLD, Ometto AR (2014) Life cycle assessment of the sugarcane bagasse electricity generation in Brazil. Renew Sust Energ Rev 32:532-547. https://doi.org/10.1016/j.rser. 2013.12.056

Silva JF, de Carvalho AM, Rein TA, Coser TR, Ribeiro Júnior WQ, Vieira DL, Coomes DA (2017) Nitrous oxide emissions from 
sugarcane fields in the Brazilian Cerrado. Agric Ecosyst Environ 246:55-65. https://doi.org/10.1016/j.agee.2017.05.019

Silva-Olaya AM, Cerri CEP, La Scala N, Dias CTS, Cerri CC (2013) Carbon dioxide emissions under different soil tillage systems in mechanically harvested sugarcane. Environ Res Lett 8:015014. https://doi.org/10.1088/1748-9326/8/1/015014

Silveira HCS, Schmidt-Carrijo M, Seidel EH, Scapulatempo-Neto C, Longatto-Filho A (2013) Emissions generated by sugarcane burning promote genotoxicity in rural workers: a case study in Barretos, Brazil. Environ Health 12:87. https://doi.org/10.1186/1476-069X12-87

Singh AK, Lal M, Suman A (2008) Effect of intercropping in sugarcane (Saccharum complex hybrid) on productivity of plant cane - ratoon system. Indian J Agron 53:140-144

Siqueira Neto M, Galdos MV, Feigl BJ, Cerri CEP, Cerri CC (2016) Direct $\mathrm{N}_{2} \mathrm{O}$ emission factors for synthetic $\mathrm{N}$-fertilizer and organic residues applied on sugarcane for bioethanol production in CentralSouthern Brazil. Glob Change Biol Bioenergy 8:269-280. https:// doi.org/10.1111/gcbb.12251

Six J, Elliott ET, Paustian K (1999) Aggregate and soil organic matter dynamics under conventional and no-tillage systems. Soil Sci Soc Am J 63:1350-1358. https://doi.org/10.2136/sssaj1999.6351350x

Smeets E, Junginger M, Faaij A, Walter A, Dolzan P (2006) Sustainability of Brazilian bio-ethanol. Report NWS-E-2006-110. Copernicus InstituteDepartment of Science, Technology and Society, Utrecht University and State University of Campinas. http://www.neema.ufc.br/Etanol25.pdf. Accessed 20 Sept 2015

Smeets E, Junginger M, Faaij A, Walter A, Dolzan P, Turkenburg W (2008) The sustainability of Brazilian ethanol — an assessment of the possibilities of certified production. Biomass Bioenergy 32: 781-813. https://doi.org/10.1016/j.biombioe.2008.01.005

Smith P, Martino D, Cai Z, Gwary D, Janzen H (2007) Policy and technological constraints to implementation of greenhouse gas mitigation options in agriculture. Agric Ecosyst Environ 118:6-28. https:// doi.org/10.1016/j.agee.2006.06.006

Soares JR, Cantarella H, Menegale MLD (2012) Ammonia volatilization losses from surface-applied urea with urease and nitrification inhibitors. Soil Biol Biochem 52:82-89. https://doi.org/10.1016/j.soilbio. 2012.04.019

Soares JR, Cantarella H, Vargas VP, Carmo JB, Martins AA, Sousa RM, Andrade CA (2015) Enhanced-efficiency fertilizers in nitrous oxide emissions from urea applied to sugarcane. J Environ Qual 44:423430. https://doi.org/10.2134/jeq2014.02.0096

Souza GS, Souza ZM, Silva RB, Barbosa RS, Araújo FS (2014) Effects of traffic control on the soil physical quality and the cultivation of sugarcane. Rev Bras Ci Solo 38:135-146. https://doi.org/10.1590/ S0100-06832014000100013

Souza RA, Telles TS, Machado W, Hungria M, Tavares Filho J (2012) Effects of sugarcane harvesting with burning on the chemical and microbiological properties of the soil. Agric Ecosyst Environ 155:16. https://doi.org/10.1016/j.agee.2012.03.012

Sparovek G, Barretto A, Berndes G, Martins S, Maule R (2009) Environmental, land-use and economic implications of Brazilian sugarcane expansion 1996-2006. Mitig Adapt Strateg Glob Chang 14:285-298. https://doi.org/10.1007/s11027-008-9164-3

Sterling SM, Ducharne A, Polcher J (2013) The impact of global landcover change on the terrestrial water cycle. Nat Clim Chang 3:385390. https://doi.org/10.1038/nclimate1690

Strassburg BBN, Latawiec AE, Barioni LG, Nobre CA, da Silva VP, Valentim JF, Vianna M, Assad ED (2014) When enough should be enough: improving the use of current agricultural lands could meet production demands and spare natural habitats in Brazil. Glob Environ Chang 28:84-97. https://doi.org/10.1016/j.gloenvcha.2014.06.001

Teshome Z, Fantaye A, Hagos H (2015) Effect of nitrogen and phosphorus on yield components, yield and sugarcane juice quality parameters of soybean-sugarcane intercropping at Tendaho sugar factory.
Biochem Physiol 4:1-4. https://doi.org/10.4172/2168-9652. 1000151

Tilman D, Cassman KG, Matson PA, Naylor R, Polasky S (2002) Agricultural sustainability and intensive production practices. Nature 418:671-677. https://doi.org/10.1038/nature01014

Tilman D, Socolow R, Foley JA, Hill J, Larson E (2009) Energy. Beneficial biofuels - the food, energy, and environment trilemma. Science 325:270-271. doi:https://doi.org/10.1126/science.1177970

Timilsina GR, Shrestha A (2011) How much hope should we have for biofuels? Energy 36:2055-2069. https://doi.org/10.1016/j.energy. 2010.08.023

Tsao CC, Campbell JE, Mena-Carrasco M, Spak SN, Carmichael GR (2011) Increased estimates of air-pollution emissions from Brazilian sugar-cane ethanol. Nat Clim Chang 2:53-57. https://doi. org/10.1038/nclimate 1325

Tullberg JN, Yule DF, McGarry D (2007) Controlled traffic farmingfrom research to adoption in Australia. Soil Till Res 97:272-281. https://doi.org/10.1016/j.still.2007.09.007

UNICA (2017) Union of the Sugarcane industries. Unicadata, Área cultivada com cana-de-açúcar, Mapeamento de área Centro-sul http://www.unicadata.com.br/. Accessed 15 July 2017

Urquiaga S, Xavier RP, de Morais RF, Batista RB, Schultz N (2012) Evidence from field nitrogen balance and $15 \mathrm{~N}$ natural abundance data for the contribution of biological N2 fixation to Brazilian sugarcane varieties. Plant Soil 356:5-21. https://doi.org/10.1007/ s11104-011-1016-3

Valentine J, Clifton-Brown J, Hastings A, Robson P, Allison G, Smith P (2012) Food vs. fuel: the use of land for lignocellulosic 'next generation' energy crops that minimize competition with primary food production. Glob Change Biol Bioenergy 4:1-19. https://doi.org/10. 1111/j.1757-1707.2011.01111.x

Velasco A, Rodríguez J, Castillo R, Ortíz I (2012) Residues of organochlorine and organophosphorus pesticides in sugarcane crop soils and river water. J Environ Sci Health 47:833-841. https://doi.org/10. 1080/03601234.2012.693864

Verstegen JA, van der Hilst F, Woltjer G, Karssenberg D, de Jong SM, Faaij APC (2016) What can and can't we say about indirect land-use change in Brazil using an integrated economic - land-use change model? Glob Change Biol Bioenergy 8:561-578. https://doi.org/10. $1111 /$ gcbb. 12270

Vieira-Megda MX, Mariano E, Leite JM, Franco HCJ, Vitti AC, Megda MM, Khan SA, Mulvaney RL, Trivelin PCO (2015) Contribution of fertilizer nitrogen to the total nitrogen extracted by sugarcane under Brazilian field conditions. Nutr Cycl Agroecosys 101:241-257. https://doi.org/10.1007/s10705-015-9676-7

Vinutha KS, Rayaprolu L, Yadagiri K, Umakanth AV, Patil JV (2014) Sweet sorghum research and development in India: status and prospects. Sugar Tech 16:133-143. https://doi.org/10.1007/s12355-014-0302-9

Vitti AC, Trivelin PCO, Gava GJC, Penatti CP, Bologna IR, Faroni CE, Franco HCJ (2007) Produtividade da cana-de-açúcar relacionada ao nitrogênio residual da adubação e do sistema radicular. Pesq Agropec Bras 42:249-256. https://doi.org/10.1590/S0100204X2007000200014

von Blottnitz H, Curran MA (2007) A review of assessments conducted on bio-ethanol as a transportation fuel from a net energy, greenhouse gas, and environmental life cycle perspective. J Clean Prod 15:607619. https://doi.org/10.1016/j.jclepro.2006.03.002

Walter A, Dolzan P, Quilodrán O, de Oliveira JG, da Silva C, Piacente F, Segerstedt A (2011) Sustainability assessment of bio-ethanol production in Brazil considering land use change, GHG emissions and socio-economic aspects. Energy Policy 39:5703-5716. https://doi. org/10.1016/j.enpol.2010.07.043

Walter A, Galdos MV, Scarpare FV, Leal MRLV, Seabra JEA, da Cunha MP, Picoli MCA, de Oliveira COF (2014) Brazilian sugarcane ethanol: developments so far and challenges for the future. WIRES Energy Environ 3:70-92. https://doi.org/10.1002/wene.87 
Warren N, Allan IJ, Carter JE, House WA, Parker A (2003) Pesticides and other microorganic contaminants in fresh water sedimentary environments—a review. Appl Geochem 18:159-194. https://doi.org/ 10.1016/S0883-2927(02)00159-2

West TO, Marland G (2002) A synthesis of carbon sequestration, carbon emissions, and net carbon flux in agriculture: comparing tillage practices in the United States. Agric Ecosyst Environ 91:217-232. https://doi.org/10.1016/S0167-8809(01)00233-X

Wortmann CS, Liska AJ, Ferguson RB, Lyon DJ, Klein RN (2010) Dryland performance of sweet sorghum and grain crops for biofuel in Nebraska. Agron J 102:319-326. https://doi.org/10.2134/ agronj2009.0271
Yang W, Li Z, Wang J, Wu P, Zhang Y (2013) Crop yield, nitrogen acquisition and sugarcane quality as affected by interspecific competition and nitrogen application. Field Crops Res 146:44-50. https://doi.org/10.1016/j.fcr.2013.03.008

Yeh S, Berndes G, Mishra GS, Wani SP, Elia Neto A (2011) Evaluation of water use for bioenergy at different scales. Biofuels Bioprod Biorefin 5:361-374. https://doi.org/10.1002/bbb.308

Zilberman D (2017) Indirect land use change: much ado about (almost) nothing. Glob Change Biol Bioenergy 9:485-488. https://doi.org/ $10.1111 / \mathrm{gcbb} .12368$ 